\title{
Supraglacial drainage efficiency of the Greenland Ice Sheet estimated from remote sensing and climate models
}

Kang Yang ${ }^{1,2,3}$, Laurence C. Smith ${ }^{4,5}$, Lauren C. Andrews ${ }^{6}$, Xavier Fettweis ${ }^{7}$, Manchun Li $i^{1,2}$

1. School of Geography and Ocean Science, Nanjing University, Nanjing, China

2. Frontiers Science Center for Critical Earth Material Cycling, Nanjing University, Nanjing, China

3. Southern Marine Science and Engineering Guangdong Laboratory, Zhuhai, China

4. Institute at Brown for Environment and Society, Providence, RI, USA

5. Department of Earth, Environmental \& Planetary Sciences, Brown University, Providence, $\mathrm{RI}, \mathrm{USA}$

6. Global Modeling and Assimilation Office, NASA Goddard Space Flight Center, Greenbelt, MD, USA

7. Department of Geography, University of Liège, Liège 4000, Belgium

Corresponding author: Kang Yang; Email: kangyang@nju.edu.cn

This article has been accepted for publication and undergone full peer review but has not been through the copyediting, typesetting, pagination and proofreading process, which may lead to differences between this version and the Version of Record. Please cite this article as doi: 10.1029/2021JF006269.

This article is protected by copyright. All rights reserved. 
Abstract: Supraglacial stream/river catchments drain large volumes of surface meltwater off the southwestern Greenland Ice Sheet (GrIS) surface. Previous studies note a strong seasonal evolution of their drainage density $\left(D_{d}\right)$, a classic measure of drainage efficiency defined as open channel length per unit catchment area, but a direct correlation between $D_{d}$ and surface meltwater runoff $(R)$ has not been established. We use 27 high-resolution ( $0.5 \mathrm{~m})$ satellite images to map seasonally evolving $D_{d}$ for four GrIS supraglacial catchments, with elevations ranging from $1100 \mathrm{~m}$ to $1700 \mathrm{~m}$. We find a positive linear correlation $\left(r^{2}=0.70\right.$, $p<0.01$ ) between $D_{d}$ and simulations of runoff production from two climate models (MAR v3.11 and MERRA-2). Applying this $R-D_{d}$ empirical relationship to climate model output enables parameterization of spatial and temporal changes in supraglacial drainage efficiency continuously throughout the melt season, although temporal and spatial skewness of $D_{d}$ observations likely affects the application of this $R-D_{d}$ relationship on crevasse fields and snow/firn surfaces. Incorporating this information into a simple surface routing model finds that high runoff leads to earlier, larger diurnal peaks of runoff transport on the ice surface, owing to increased $D_{d}$. This effect progressively declines from low ( $\left.1100 \mathrm{~m}\right)$ to high ( 1700 m) elevation, causing a roughly order-of-magnitude reduction in diurnal runoff variability at the highest elevations relative to standard climate model output. Combining intermittent satellite $D_{d}$ mapping with climate model output thus promises to improve characterization of supraglacial drainage efficiency to the benefit of supraglacial meltwater routing and subglacial hydrology models.

Plain Language Summary: Supraglacial streams and rivers are fed by meltwater runoff and are widely distributed on the Greenland Ice Sheet (GrIS). However, a direct correlation

This article is protected by copyright. All rights reserved. 
between stream abundance and surface meltwater runoff production has not previously been established. This introduces uncertainty surrounding the diurnal timing and magnitude of runoff entering moulins, which in turn limits our physical understanding of short-term hydrodynamic ice motion. By correlating climate model runoff simulations with intermittent high-resolution satellite maps of supraglacial streams, we find a positive correlation between modeled runoff and satellite-mapped stream drainage density along an elevational gradient of the southwestern GrIS. This finding opens the door for parameterizing surface runoff routing efficiency directly from climate model output, and reveals existence of elevational gradients in moulin input timing and subglacial water pressure caused solely by lower supraglacial stream drainage density at higher ice sheet elevations.

Key words: meltwater runoff, drainage density, flow routing, moulin, Greenland Ice Sheet

This article is protected by copyright. All rights reserved. 


\section{Introduction}

Supraglacial streams and rivers are widely distributed on the Greenland Ice Sheet (GrIS) ablation zone (Smith et al., 2015; Yang and Smith, 2016; Pitcher and Smith, 2019). In southwestern GrIS, virtually all terminate in moulins, forming numerous internally drained catchments on the ice surface that deliver large volumes of surface meltwater runoff $(R)$ to the bed (Banwell et al., 2013; Clason et al., 2015; Smith et al., 2015; Banwell et al., 2016; de Fleurian et al., 2016; Yang and Smith, 2016; Smith et al., 2017; Andrews et al., 2021; Smith et al., 2021). Field-calibrated surface routing models suggest that this runoff passes quickly $\left(\sim 10^{-1} \mathrm{~m} / \mathrm{s}\right)$ through supraglacial stream/river channels, but slowly $\left(\sim 10^{-3}-10^{-4} \mathrm{~m} / \mathrm{s}\right)$ through surrounding interfluves (Yang et al., 2018). Indeed, the interfluve meltwater routing velocity may be two orders of magnitude lower $\left(\sim 10^{-6} \mathrm{~m} / \mathrm{s}\right)$ if rills and micro-channels do not exist in the interfluve zone (Irvine-Fynn et al., 2021). This dichotomy of fast vs. slow flow between open channels and interfluves controls the timing and magnitude of diurnally varying moulin input, which in turn influences subglacial hydrology and ice flow dynamics (Schoof, 2010; Banwell et al., 2013; Andrews et al., 2014; Clason et al., 2015; de Fleurian et al., 2016;

Decaux et al., 2018; Koziol and Arnold, 2018; Davison et al., 2019; Poinar and Andrews, 2020; Smith et al., 2021). Accurate simulation of moulin input hydrographs therefore requires highresolution, multi-temporal mapping of supraglacial stream/river networks, so as to partition catchment drainage areas into channelized vs. non-channelized flow (Yang et al., 2018).

While supraglacial rivers are sufficiently large (>10 m wide) to detect in Landsat- 8 and Sentinel-2 visible/near-infrared satellite imagery (Lampkin and VanderBerg, 2014; Poinar et al., 2015; Yang and Smith, 2016), smaller (<10 m wide) supraglacial streams are narrow and

This article is protected by copyright. All rights reserved. 
discernable only in very high resolution (VHR, $<2 \mathrm{~m}$ ) satellite or drone images (McGrath et al., 2011; Yang and Smith, 2013; Rippin et al., 2015; Smith et al., 2015; King et al., 2016; Smith et al., 2017; Decaux et al., 2018). Due to limited spatial and temporal coverage, VHR supraglacial stream maps are relatively rare. This limits understanding of how spatial and seasonal variations in supraglacial stream development influence supraglacial drainage efficiency and diurnal discharge cycles delivered to moulins.

Climate models provide daily or hourly simulations of surface meltwater runoff (Fettweis et al., 2020). Because supraglacial channels are fed by meltwater runoff, their pattern and abundance evolves temporally in response to surface meltwater production (Lampkin and VanderBerg, 2014; Smith et al., 2017; Yang et al., 2017; Decaux et al., 2018; Yang et al., 2018; Pitcher and Smith, 2019; Muthyala et al., 2020; Gleason et al., 2021). Previous studies have noted some qualitative relationships between channel planforms and modeled runoff, e.g. becoming wider as surface runoff increases (Smith et al., 2015; Yang et al., 2017), migrating to higher elevations (Lampkin and VanderBerg, 2014), or growing in area as modeled runoff increases (Lu et al., 2020; Yang et al., 2021). However, an explicit, quantitative correlation linking remotely sensed supraglacial stream/river abundance with modeled runoff has yet to be demonstrated.

Drainage density $D_{d}\left(\mathrm{~km}^{-1}\right)$ is a terrestrial hydrology measure of stream abundance defined as the total stream length $(\mathrm{km})$ within a catchment divided by the catchment area $\left(\mathrm{km}^{2}\right)$ (Dingman, 2015). $D_{d}$ is controlled primarily by climate (Montgomery and Dietrich, 1989), with topography and saturated soil conductivity as secondary factors (Abrahams, 1984). On the ice sheet surface, surface meltwater runoff production analogously plays a

This article is protected by copyright. All rights reserved. 
primary role in controlling $D_{d}$, with ice surface topography (Crozier et al., 2018; Ignéczi et al., 2018) and permeability of weathering crust/firn/wet snow (Cooper et al., 2018; Irvine-Fynn et al., 2021) as secondary factors. The large supraglacial river main-stems do not expand or contract in length considerably during the melt season (Smith et al., 2015) so they have marginal impact on $D_{d}$. In contrast, the abundant small streams expand and contract quickly (diurnally) as a response to diurnal surface runoff inputs, analogous to their terrestrial counterparts (Godsey and Kirchner, 2014; Allen et al., 2018; Prancevic and Kirchner, 2019; van Meerveld et al., 2019). Therefore, $D_{d}$ has potential to vary sensitively in response to different surface runoff intensities.

Here, we present empirical evidence of a correlation between remotely sensed supraglacial stream $D_{d}$ and climate model outputs of surface runoff $(R)$ on the southwestern GrIS. For four supraglacial catchments, we compare runoff from two climate models with VHR imagery and find a positive linear $R-D_{d}$ relationship. Next, we apply this relationship to a spatially-lumped surface routing model, rescaled width function (RWF, Yang et al. (2018)), to assess the influence of temporal and spatial differences in $D_{d}$ on diurnal surface runoff cycles. A sensitivity analysis is also conducted to ascertain the relative importance of surface runoff on supraglacial drainage efficiency versus those of two previously reported factors, namely catchment area (Smith et al., 2017) and topographic slope (Banwell et al., 2012). From this analysis, we identify strong seasonal and elevational gradients in GrIS supraglacial drainage efficiency, caused by predictable runoff seasonality and lower $D_{d}$ at higher elevations, respectively. We conclude by discussing some broader scientific implications of our findings, and promising directions for future research.

This article is protected by copyright. All rights reserved. 


\section{Study area and Data}

Four supraglacial catchments with good archival coverage by satellite VHR images and spanning an 1100-1700 m elevation gradient along the southwestern GrIS ablation zone were selected for study (Figure 1, Tables 1 and S1). This general area exhibits high surface melt intensity and has been widely used to study GrIS supraglacial hydrology (Sundal et al., 2009; Fitzpatrick et al., 2014; Smith et al., 2015; Yang and Smith, 2016; Smith et al., 2017; Cooper et al., 2018; Smith et al., 2021). These four selected catchments, hereafter called Catchments 1-4, span a range of elevational bands with differing surface conditions and melt intensities (Fitzpatrick et al., 2014). These elevation bands include: 1000-1200 m (heavily crevassed); 1200-1400 m (numerous supraglacial streams, rivers, and lakes); 1400-1600 m (near the end-of-summer snowline $1549 \pm 144$ m during 2009-2015, Ryan et al. (2019)); and >1600 m (firn/snow). Catchments 1-4 also capture a previously reported general pattern of increasing catchment area at higher ice surface elevations (Yang and Smith, 2016; Smith et al., 2017). An additional four Catchments m1-m4, including previously published supraglacial stream networks manually digitized from $0.5 \mathrm{~m}$ WorldView panchromatic imagery (Smith et al., 2015; King et al., 2016), were used for independent validation (Figure 1).

Mosaics of $5 \mathrm{~m}$ ArcticDEM v2.0 digital elevation data were used to delineate supraglacial catchment boundaries. ArcticDEM is produced by the University of Minnesota Polar Geospatial Center (PGC, https://www.pgc.umn.edu/) using stereo photogrammetrical processing of VHR satellite imagery. ArcticDEM is the highest spatial resolution DEM available for the GrIS and has been widely used in ice sheet hydrology studies (Smith et al.,

This article is protected by copyright. All rights reserved. 
2017; Crozier et al., 2018; Yang et al., 2018; Yang et al., 2019b; Lu et al., 2020). Importantly, it can discriminate continuous supraglacial drainage networks that match the general pattern of satellite-mapped supraglacial river/stream networks quite well (Yang et al., 2018; Gleason et al., 2021), although it may overestimate or underestimate streams depending on the choice of the channel initiation threshold $A_{c}$ (Yang et al., 2019b; Lu et al., 2020). The $5 \mathrm{~m}$ mosaic ArcticDEM product was used because of its sufficient resolution for representing interfluve routing distance (Yang et al., 2018), and its higher computational efficiency compared to the $2 \mathrm{~m}$ tile ArcticDEM v2.0 product.

Twenty-seven scenes of VHR panchromatic WorldView-1/2/3 (0.5 m) and Quickbird (0.61 m) satellite imagery acquired during 2009-2015 were obtained from PGC to delineate supraglacial stream networks within Catchments 1-4 (Table S1 and Figure S1). The spatial resolution of the single Quickbird scene was resampled to $0.5 \mathrm{~m}$ for consistency with the WorldView-1/2/3 scenes. Yang et al. (2018) compared $0.5 \mathrm{~m}$ WorldView VHR images with even higher resolution (0.2 m) fixed-wing drone images (Smith et al., 2017) and found that $0.5 \mathrm{~m}$ WorldView images accurately discern small supraglacial streams. Therefore, $0.5 \mathrm{~m}$ satellite VHR images enable accurate partitioning of supraglacial open channels and interfluves and may be satisfactorily used to estimate supraglacial stream drainage density. However, 26 out of 27 VHR satellite images were acquired at a similar time of day (12:00 15:00, Western Greenland summer time, Table $\mathbf{S 1}$ ) precluding a satellite-based assessment of $D_{d}$ diurnal variability.

Two climate models, the regional climate model MAR v3.11 and the atmospheric reanalysis MERRA-2, were used to estimate daily surface meltwater runoff $(R)$ over our study

This article is protected by copyright. All rights reserved. 
area (Figure 1). Both models have been previously used for supraglacial hydrology studies of the southwestern GrIS (Smith et al., 2017; Yang et al., 2019a). MAR v3.11 was also used to approximate hourly runoff values. MAR v3.11 is driven by ERA-5 reanalysis at its lateral boundaries and is here applied at a spatial resolution of $7.5 \mathrm{~km}$ (Fettweis et al., 2020). MERRA-2 is a global atmospheric reanalysis produced by the NASA Global Modeling and Assimilation Office (GMAO) with a horizontal spatial resolution of $56 \times 28 \mathrm{~km}$ in southwestern GrIS (Bosilovich et al., 2016; Reichle et al., 2017). The temporal resolution of MERRA-2 is three hours so it cannot be used for hourly runoff modeling.

A $\sim 0.78 \mathrm{~km}$ resolution surface albedo product of Greenland developed from standard MODerate-resolution Imaging Spectroradiometer (MODIS) images (Hall et al., 2018) was used to calculate daily surface albedos of the four supraglacial catchments.

\section{Methods}

\subsection{Supraglacial catchment boundary delineation}

Supraglacial catchment boundaries were extracted from $5 \mathrm{~m}$ ArcticDEM mosaic rasters following Karlstrom and Yang (2016). The topographic depression breaching method of Lindsay (2016) was used to determine supraglacial flow direction and flow accumulation following Gleason et al. (2021). Supraglacial catchment outlets were manually identified and used as pour points to generate upstream catchment boundaries, following Karlstrom and Yang (2016).

\subsection{Surface runoff and albedo calculations}

This article is protected by copyright. All rights reserved. 
For each catchment, values of runoff (in $\mathrm{mm}$ ) were extracted from MAR v3.11 and MERRA-2 model outputs at daily or hourly resolution by clipping model grid cells with the catchment polygon boundary and averaging their values (Pitcher et al., 2016). Because the runoff in MAR v3.11 is already delayed by an internal routing function (Zuo and Oerlemans, 1996; Lefebre et al., 2003), it cannot be used as input for another routing model. We computed instantaneous runoff instead (melt + rainfall + condensation - retention refreeze, Vernon et al. (2013)) for the following routing analysis, as per Smith et al. (2017). Similarly, for each catchment, surface albedo values were extracted from the MODIS data product by clipping it with the catchment polygon boundary and averaging their values. To discriminate between bare ice and firn/snow, we used an albedo threshold of $<0.55$ (Ryan et al., 2019).

\subsection{Spatial and temporal variations in supraglacial drainage density $\left(D_{d}\right)$}

Supraglacial stream networks were delineated from the 27 scenes of VHR $(0.5 \mathrm{~m})$ panchromatic satellite images following the method of Yang et al. (2017). First, a band pass filter (ramped between $1 / 200$ and $1 / 10 \mathrm{~m}^{-1}$ ) was applied to remove low frequency image background and high frequency image noise. Second, a Gabor filter with a thickness of 2 pixels was used to enhance narrow supraglacial stream channels from the image background. The minimum path length is set to 20 pixels to enhance the longitudinal continuity of short stream channels. Third, a path opening morphological operator was used to enhance longitudinal connectivity of stream channels. Fourth, a global threshold (set to 25 out of 255) was used to classify the enhanced image and generate a raster stream mask. This

This article is protected by copyright. All rights reserved. 
global threshold was empirically determined to achieve a good balance of small stream identification and background noise suppression, which has been successfully applied in previous studies (Yang et al., 2018; Yang et al., 2019b; Lu et al., 2020). Finally, the raster stream mask was vectorized to produce supraglacial stream polylines, from which the supraglacial stream $D_{d}$ of each supraglacial catchment was then calculated $\left(D_{d}=\right.$ total stream length / area of the catchment covered by VHR imagery).

For this study, we hypothesized that a positive relationship exists between modeled runoff $(R)$ and remotely sensed $D_{d}$, and used linear regression to quantify this $R-D_{d}$ relationship for our four study catchments. Our motivation is that a stable $R-D_{d}$ relationship, if found, could be used to predict time-varying estimates of $D_{d}$ simply from climate model outputs of runoff. For independent validation of the regression model, we use previously published manually digitized supraglacial stream maps for Catchments m1-m4 in the area (Smith et al., 2015; King et al., 2016).

\subsection{Spatial and temporal patterns in channel initiation threshold $\left(A_{c}\right)$}

A second metric we use to characterize supraglacial drainage efficiency is the channel initiation threshold $A_{c}$ (Montgomery and Dietrich, 1989). $A_{c}$ is the total cumulative upstream contributing area (in $\mathrm{m}^{2}$ ) required to initiate an open channel on the landscape surface. It tends to have an inverse relationship with drainage density, with high $D_{d}$ values associated with low $A_{c}$ values (i.e. abundant supraglacial streams separated by small interfluves), and low $D_{d}$ values associated with high $A_{c}$ values (i.e. fewer, less extensive supraglacial streams separated by large interfluves). To simulate this effect, we used the ExtractStreams tool in

This article is protected by copyright. All rights reserved. 
the WhiteboxTools-Python (https://whitebox.readthedocs.io/en/latest/index.html) to generate multiple supraglacial drainage networks from the flow accumulation grid based on a stepwise increase in $A_{c}$ values (ranging from $25 \mathrm{~m}^{2}$ to $2.5 \times 10^{5} \mathrm{~m}^{2}$ with a step of $25 \mathrm{~m}^{2}$ ) applied to the $5 \mathrm{~m}$ ArcticDEM data. All pixels with flow accumulation values larger than a given $A_{c}$ value are classified as open channel pixels, and others classified as interfluve pixels, following conventional hydrological analysis (Tarboton et al., 1991).

Next, we calculated the corresponding $D_{d}$ values associated with each stepwise value of $A_{c}$. Correlation of the two variables yields an empirical $D_{d}-A_{c}$ relationship for each of the four study catchments. As such, for a given $D_{d}$ value, a corresponding $A_{c}$ value may be determined and then used to generate a physically realistic supraglacial drainage network from the $5 \mathrm{~m}$ ArcticDEM data. Note the $D_{d}-A_{c}$ relationship is scale-dependent and varies across different spatial resolution DEMs (Goulden et al., 2014; Yang et al., 2014). Therefore, the obtained $D_{d}$ $A_{c}$ relationship is only appropriate for use with the $5 \mathrm{~m}$ resolution ArcticDEM.

Following these steps, corresponding values of $D_{d}$ and $A_{c}$ may be calculated for a given modeled value of runoff, and a physically realistic supraglacial drainage network may be simulated from ArcticDEM. Using continuous climate model output of runoff, the evolving supraglacial stream networks are simulated, and then used as input to a surface routing model to investigate temporal changes in supraglacial drainage efficiency and surface runoff cycles. Because the images were acquired at a similar time of day (Table S1), supraglacial drainage efficiency is assumed constant for time periods $<24$ hours, to allow daily climate model output to drive seasonally change in $D_{d}$ and $A_{c}$.

This article is protected by copyright. All rights reserved. 


\subsection{Surface meltwater runoff routing}

For each given supraglacial stream network in each study catchment, we drove the rescaled width function (RWF) routing model of Yang et al. (2018) with MAR and MERRA-2 runoff outputs to the outlet of each catchment. The RWF model is spatially "lumped" but assumes two bulk (catchment-averaged) water velocities, through open channels $\left(v_{c}\right)$ and interfluves $\left(v_{h}\right)$, respectively. Field-calibrated values of $v_{c}$ and $v_{h}$ are available for Catchment 2 (i.e. part of Rio Behar catchment) from Yang et al. (2018). For Catchments 1, 3, and 4, the method of Miller et al. (1994) is used to adjust $v_{c}$ and $v_{h}$ as follows:

$$
v_{c}=v_{c 0} \sqrt{s / s_{o}}, v_{h}=v_{h 0} \sqrt{s / s_{o}}
$$

where $v_{c 0}=0.4 \mathrm{~m} / \mathrm{s}$ and $v_{h 0}=0.0006 \mathrm{~m} / \mathrm{s}$ are mean open-channel and interfluve water velocities derived from field measurements in Catchment $2, s_{0}=0.034 \mathrm{~m} / \mathrm{m}$ is the mean slope of Catchment 2, and $s$ is the mean slope for each of the other three catchments.

The core approach of the RWF surface routing model is to create a catchment-specific unit hydrograph (UH) that distinguishes between interfluve (i.e. hillslope) and open-channel flow. To achieve this, RWF uses input supraglacial stream networks to partition each catchment into interfluve and open-channel zones, calculates corresponding routing distances $\left(L_{h}\right.$ and $\left.L_{c}\right)$ for each, then estimates the routing time for each catchment pixel as:

$$
t=t_{h}+t_{c}=L_{h} / v_{h}+L_{c} / v_{c}
$$

where $t_{h}$ is the interfluve routing time and $t_{c}$ is the channel routing time. Hourly (or daily) binning the histogram of the routing time raster yields a one hour (or day) $\mathrm{UH}$, which determines the response function of how one "unit" ( $1 \mathrm{~mm} /$ hour or $1 \mathrm{~mm} /$ day) of modeled instantaneous runoff is routed to the catchment outlet (Smith et al., 2017). The routed

This article is protected by copyright. All rights reserved. 
runoff ( $\left.R_{\text {routed }}\right)$ at the catchment outlet is then calculated as:

$$
R_{\text {routed }}=R * \mathrm{UH}
$$

where ${ }^{*}$ is a convolution operator (Dingman, 2015). UH conserves mass and its unit is hour ${ }^{-1}$ or day ${ }^{-1}$. The final outcome of this procedure is a routed meltwater runoff hydrograph at the outlet of each of the four catchments, at either a daily or hourly time step depending on choice of climate model output and UH (Yang et al., 2018).

\subsection{Sensitivity analysis}

The model diurnal runoff signal from each catchment is dependent on drainage density $D_{d}$, which is controlled primarily by runoff; and by prescribed water velocity, which is controlled by topographic slope (Eq. 1); and by catchment area, which determines the total routing distance for surface meltwater. These characteristics are closely linked, making it difficult to isolate the impact of any individual characteristic while retaining realistic modeled runoff.

To evaluate the relative roles of runoff, catchment area, and topographic slope (velocity), we performed several inter-comparisons. These inter-comparisons use runoff derived from Catchments 1 through 4, and a small sub-catchment (Catchment 4-1), with an area of $7.8 \mathrm{~km}^{2}$ (similar to the area of Catchment 1, inside Catchment 4; Figure 1) and the methods described above. In addition, we also modeled runoff using field-calibrated water velocities (i.e. $v_{c 0}=0.4 \mathrm{~m} / \mathrm{s}$ and $v_{h 0}=0.0006 \mathrm{~m} / \mathrm{s}$ ) without adjusting for catchment topographic slope (Eq. 1).

Comparison 1: To examine the relative importance of instantaneous runoff magnitude,

This article is protected by copyright. All rights reserved. 
we compared Catchment 1 outputs to Catchment 4-1 outputs using field-calibrated water velocities. This comparison minimizes differences in catchment area and removes differences in velocities allowing us to isolate the impact of runoff production on $D_{d}$ and subsequent diurnal variability of routed catchment runoff (as Catchment 1 has the highest melt rates and Catchment 4-1 has the lowest melt rates for any given day).

Comparison 2: To examine the relative importance of catchment area, we compared Catchment 4 outputs to Catchment 4-1 outputs using field-calibrated velocities. This comparison minimizes the differences in meltwater runoff magnitude (because Catchment 41 is part of Catchment 4) and removes the impact of topographic slope on water velocity, allowing us to isolate the impact of catchment area on diurnal variability of routed catchment runoff.

Comparison 3: To examine the relative importance of topographic slope (velocity), we compared Catchment 4 runoff routed with field-calibrated velocities and slope-adjusted velocities (as determined from Eq. 1). The difference in slopes nearly spans the range of slopes observed in Catchments 1 through 4. Performing this comparison using Catchment 4 magnifies the observable differences as larger catchment area and longer routing distance heighten the relative importance of flow velocity on routing efficiency.

Overall, these three comparisons do not act as a true sensitivity study, but provide useful insight on how relevant variables impact routed catchment runoff under a typical range of surface conditions found on this area of the GrIS.

\section{Results}

This article is protected by copyright. All rights reserved. 


\subsection{Correlation of supraglacial drainage density $\left(D_{d}\right)$ with modeled runoff $(R)$}

Using VHR satellite imagery, supraglacial stream networks in the four studied supraglacial catchments were mapped 27 times in total (Figures $\mathbf{2}$ and S2-S5). The resultant $D_{d}$ values range from $0.3 \mathrm{~km}^{-1}$ to $81.3 \mathrm{~km}^{-1}$. On 31 July 2012 , during a period of extreme surface melting (Nghiem et al., 2012; Tedesco et al., 2013), the measured $D_{d}$ of Catchment 3 is $81.3 \mathrm{~km}^{-1}$, an extraordinarily high $D_{d}$ value that has not previously been reported (Figure S2). A total of 26 out of 27 images were acquired during 12:00 - 15:00, local Greenland time (Table S1). Therefore, we assume that the resultant $D_{d}$ is smaller than but comparable to the peak diurnal $D_{d}$ value (Text S1).

A positive linear relationship is found between satellite-mapped drainage density $D_{d}$ and modeled runoff (Figures 3a-3b). Optimal regression coefficients $\left(r^{2}=0.70\right)$ for both MAR and MERRA-2 (Figure 3) are achieved when runoff is smoothed using an antecedent five day moving average (i.e. replacing the runoff of each day with the average runoff of the preceding five days). As a result, an identical regression coefficient was obtained for the MAR and MERRA-2 models $\left(D_{d}=1.7 R_{\mathrm{MAR}}-4\right.$, and $\left.D_{d}=2.6 R_{\mathrm{MERRA}-2}-8, r^{2}=0.70, p<0.01\right)$. We recommend using their corresponding model-specific regression functions to handle their differing runoff estimates (Figure $\mathbf{S 1}$ ) and set the minimum $D_{d}$ to 0 as a constraint for the regression. An additional $R-D_{d}$ linear regression was conducted using $D_{d}$ and runoff values for each catchment (Figures 3c-3d). These four regressions show no significant differences ( $p>0.1$ in the Chow test, "a test of whether the true coefficients in two linear regressions on different data sets are equal", Chow (1960)) and indicate the $R$ - $D_{d}$ relationship is generally stable among the four catchments, although the limited number of regression points for

This article is protected by copyright. All rights reserved. 
Catchment $4(n=3)$ limits our confidence in that determination. This finding is consistent with previous reports that surface meltwater areas and volumes are positively correlated with modeled runoff (Sneed and Hamilton, 2007; Sundal et al., 2009; Fitzpatrick et al., 2014; Yang et al., 2017; Lu et al., 2020; Yang et al., 2021).

The seasonal $D_{d}$ observations are skewed temporally because 24 out of 27 images were acquired during or after seasonal peak melting time period (Figure S1). However, no significant temporal trends in the residuals are found between the VHR satellite-mapped and regression-calculated $D_{d}$ values (Text S2). The seasonal $D_{d}$ observations are also skewed spatially because 19 images were acquired at middle-elevation Catchments 2 and 3, while low-elevation Catchment 1 and high-elevation Catchment 4 have limited observations ( 5 and 3 times, respectively). Additionally, 22 images were covered by bare ice and only 5 images by snow/firn (Table S1). Unfortunately, the five "snow/firn" points cannot build confident $R-D_{d}$ relationships ( $p=0.05$ for MAR and 0.12 for MERRA-2) so it is not possible to confirm whether a different $R-D_{d}$ relationship should be built for snow/firn surfaces.

The $D_{d}$ values calculated from four other manually digitized stream networks in Catchments m1-m4 are slightly lower than the linear regression curves predict, except for the low-elevation ( $850 \mathrm{~m}$ ) validation catchment (King et al., 2016) where the digitized $D_{d}$ is significantly lower than the $D_{d}$ predicted from climate models (Figure 3). Two possible explanations for this difference are that manual digitization tends to miss very small streams (Smith et al., 2015), and crevasses may hinder development of supraglacial streams at low elevations (Yang and Smith, 2016). This finding suggest that the $R-D_{d}$ relationship may not hold for low-elevation crevasse fields, where surface meltwater routing paths are short and

This article is protected by copyright. All rights reserved. 
spatially distributed (Colgan et al., 2011).

When unmodified runoff is used (first column, Figure S6), the corresponding $r^{2}$ values of the $R-D_{d}$ relationships decline to 0.50 and 0.40 for MAR and MERRA-2, respectively. This finding suggests that considerable uncertainties exist in the timing and the magnitude of runoff estimates (Smith et al., 2017; Yang et al., 2019a; Fettweis et al., 2020); and/or that several days are required to form detectable supraglacial meltwater channels after melting occurs (Holmes, 1955; Marston, 1983; Knighton, 1985). Further partitioning of these two effects lies outside the scope of this study, but as a practical solution we suggest use of an antecedent 5-day moving average to smooth runoff estimates prior to computing empirical $R-D_{d}$ correlations.

\subsection{Correlation of supraglacial drainage density $\left(D_{d}\right)$ with channel initiation threshold $\left(A_{c}\right)$}

Due to its higher spatial and temporal resolution than MERRA-2, we primarily use MAR here and in following sections. For the $5 \mathrm{~m}$ ArcticDEM, we find a third order polynomial function reasonably describes this inverse $D_{d}-A_{c}$ relationship for $D_{d}<60 \mathrm{~km}^{-1}$ (and corresponding $A_{c}>10^{2} \mathrm{~m}^{2}$, Figure 4a). For $D_{d}>60 \mathrm{~km}^{-1}$ (and corresponding $A_{c}<10^{2} \mathrm{~m}$ ), which indicates extreme melting and is rare, $D_{d}-A_{c}$ curves show large variations among the four study catchments (Figure 4a). The fitting curves of low-elevation catchments 1 and 2 are steeper (mean slopes 0.035 and 0.034 ), signifying that they require smaller contributing areas to initiate supraglacial open channels, similar to terrestrial channels (Montgomery and Dietrich, 1989; Prancevic and Kirchner, 2019). The fitting curves of high-elevation Catchments 3 and 4 are flatter (mean slopes are 0.025 and 0.021 ), signifying these

This article is protected by copyright. All rights reserved. 
topographically flatter catchments require larger contributing areas to initiate supraglacial open channels.

According to the $R-D_{d}$ correlation as surface meltwater runoff increases, supraglacial stream $D_{d}$ increases and channel initiation threshold $A_{c}$ decreases (Figure $4 \mathbf{b}$ ). This finding is similar to the surface runoff production by saturation overland flow in terrestrial humid and semi-humid environments (Montgomery and Dietrich, 1989; Tucker and Bras, 1998), and suggests that surface runoff dominates the typical ranges of $D_{d}$ and $A_{c}$, i.e., $D_{d}<60 \mathrm{~km}^{-1}$ and $A_{c}>10^{2} \mathrm{~m}^{2}$. A daily MAR runoff value exceeding $>37 \mathrm{~mm} /$ day (which is rare) is required to yield a $D_{d}$ larger than $60 \mathrm{~km}^{-1}$. Under such extreme conditions, surface runoff and ice surface slope (which are constrained by DEM spatial resolution) control both $D_{d}$ and $A_{c}$ (Figure $4 \mathbf{b}$ ).

As noted earlier, there is generally an inverse relationship between drainage density $D_{d}$ and channel initiation threshold $A_{c}$. This $D_{d^{-}} A_{c}$ relationship is scale-dependent (Goulden et al., 2014) so the obtained $D_{d}-A_{c}$ curves show large variations approaching the limit of the

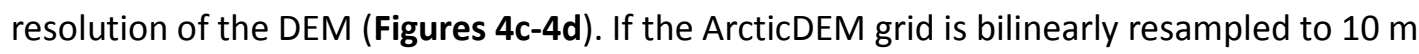
resolution, for example, increasing variability of the curves is around $D_{d}=25 \mathrm{~km}^{-1}$ rather than $60 \mathrm{~km}^{-1}$ (Figure 4). Therefore, the $10 \mathrm{~m}$ resolution ArcticDEM product cannot accurately simulate $D_{d}>25 \mathrm{~km}^{-1}$ drainage networks.

\subsection{Elevational gradients in $D_{d}$, and supraglacial drainage efficiency}

The observed $R-D_{d}$ correlations enable empirically-based modeling of temporally evolving supraglacial stream networks (i.e. drainage pattern) directly from climate model runoff simulations (Figures 3 and 4). As a simple example, the average interfluve distance $\left(L_{h}\right)$

This article is protected by copyright. All rights reserved. 
that a drop of meltwater travels to its nearest open-channel is roughly $1 /\left(4 D_{d}\right)$ (Dingman, 2015). Therefore, using the $R-D_{d}$ correlation, catchment-averaged interfluve (nonchannelized) routing time $t_{h}$ may be approximated directly using modeled runoff (Figure 5). With $v_{h}=0.0006 \mathrm{~m} / \mathrm{s}$ (Yang et al., 2018), a MAR runoff of $20 \mathrm{~mm} /$ day yields $D_{d}=30 \mathrm{~km}^{-1}$, catchment-averaged $L_{h}=8.3 \mathrm{~m}$, and $t_{h}=3.7$ hours (Figure 5 ). This approach, while purely empirical, provides a straightforward, flexible tool to roughly estimate the mean runoff routing time on the ice surface.

Moreover, the $R-D_{d}$ correlation enables partitioning of catchment interfluves and openchannel zones, permitting RWF routing of modeled runoff all the way to the catchment outlet (Figure 6). Lower runoff induces smaller $D_{d}$ and higher $A_{c}$, and thereby a contracted supraglacial stream network with larger, slower-routing interfluves - a configuration yielding flatter UHs and longer meltwater routing delays (Figure 6). In Catchment 3, for example, both hourly and daily UHs indicate that $>90 \%$ of MAR surface runoff is routed to the catchment outlet within one day if runoff exceeds $20 \mathrm{~mm} /$ day, but $<50 \%$ reaches the catchment outlet within two days if runoff is less than $10 \mathrm{~mm} /$ day.

Hourly runoff routing to the outlets of Catchments 1-4 was performed using hourly UHs (Figure 7). In the first two weeks after onset of melt, surface runoff is low and induces minimal supraglacial stream $D_{d}$, a finding supported by a contemporaneous satellite image (Figure S7). The outlet runoff hydrographs become increasingly dampened and delayed from Catchment 1 to 4 , due to lower modeled runoff (and thereby lower $D_{d}$ and higher $A_{c}$ ), slower routing velocities, and larger catchment areas at progressively higher elevations (Figure 7 and Table 1). Averaged over the 2015 melt season, the diurnal range of instantaneous (non-

This article is protected by copyright. All rights reserved. 
routed) runoff at Catchment 1 is $\sim 1.8$ times greater than Catchment 4 . After $D_{d}$-based routing is applied, this contrast in diurnal range rises to 12.4 times greater (Figure 8 and Table 1). At progressively higher elevations, the diurnal range of routed runoff decreases from $\sim 48 \%, \sim 30 \%, \sim 21 \%$, and $\sim 7 \%$ (relative to instantaneous MAR output) for Catchments 14, respectively (Figure 8). Therefore, the diurnal variability of routed surface meltwater flowing over the ice sheet become disproportionally smaller from low ( $\sim 1100 \mathrm{~m}$ where $D_{d}$ is high and surface drainage is more efficient) to high ( $1700 \mathrm{~m}$ where $D_{d}$ is low and supraglacial drainage is less efficient) elevations, with a roughly one order-of-magnitude reduction relative the standard output of climate models. The daily peak timings of routed runoff arrive at the catchment outlets 5, 8, 8, and 20 hours later for Catchments 1-4, respectively, as compared to peak MAR runoff timings (Table 1). We conclude that supraglacial drainage efficiency, driven by melting intensity, controls diurnal surface runoff timing even more than daily cycles in surface energy balance.

\subsection{The relative contribution of surface runoff, catchment area, and topographic slope}

A sensitivity analysis was conducted to further determine the relative controls of surface runoff, catchment area, and topographic slope (velocity) on the routed runoff (Table 1). In Comparison 1, we applied the field-calibrated velocities to Catchments 1 and 4-1, which have similar areas (Table 1). This allows us to examine the impact of drainage density (as modulated by runoff production) on the diurnal range and the peak time of routed runoff. The diurnal range of routed runoff for Catchment 1 is $\sim 4.1$ times greater than Catchment 4-1(Table 1), indicating that the more developed drainage density associated with

This article is protected by copyright. All rights reserved. 
elevated melt rates results in more rapid routing of surface meltwater. Further, the peak runoff time from Catchment 1 occurs 1 hour later than from Catchment 4-1.

In Comparison 2, we compared Catchment 4 outputs to Catchment 4-1 outputs using field-calibrated velocities. This comparison demonstrates that catchment area is negatively correlated with the diurnal range of routed runoff, as the diurnal range of routed runoff for Catchment $4-1$ is $\sim 1.4$ times greater than Catchment 4 (Table 1). Furthermore, the timing of peak runoff from Catchment 4-1 occurs 8 hours earlier than from Catchment 4. Viewing Comparisons 1 and 2 collectively, we suggest that surface runoff intensity is more important than catchment area in controlling the diurnal range of runoff transport, but catchment area dominates the timing of peak runoff transport.

In Comparison 3, we compared Catchment 4 runoff routed with field-calibrated velocities and slope-adjusted velocities. When faster field-calibrated velocities are applied, the diurnal range of routed runoff of Catchment 4 increases by $\sim 2.2$ times, and peak runoff timing occurs 8 hours earlier compared to slower slope-adjusted velocities (Table 1). Viewing Comparisons 1-3 collectively, we suggest that surface runoff is more important than topographic slope for controlling the diurnal range of supraglacial runoff transport, but the topographic slope dominates the peak runoff timing. Note that the diurnal range of routed runoff only increases by $\sim 1.4$ times for Catchment 4-1, confirming that longer routing distance in Catchment 4 maximizes the impact of topographic slope (velocity).

We conclude that surface runoff intensity is the most important factor controlling the diurnal range of runoff transport, but catchment area and topographic slope are most important for the timing of peak runoff delivery to the catchment outlet.

This article is protected by copyright. All rights reserved. 


\section{Discussion}

5.1 Supraglacial drainage efficiency can be characterized directly from climate model output

This study presents a first attempt to characterize supraglacial drainage efficiency directly from climate model outputs of surface runoff. Climate models typically calculate runoff as a residual of other surface mass balance variables, and ignore catchment routing and other supraglacial hydrologic processes that delay and attenuate runoff transport across the ice surface (Vernon et al., 2013; Flowers, 2018; Fettweis et al., 2020).

Such runoff delays may be simulated using climate model output to drive a surface routing model constrained with supraglacial stream maps and/or digital elevation models (Banwell et al., 2012; Leeson et al., 2012; de Fleurian et al., 2016; Smith et al., 2017; Koziol and Arnold, 2018; Yang et al., 2018; Yang et al., 2020). However, VHR satellite imagery and DEMs have limited temporal and spatial coverage (Yang and Smith, 2013; Rippin et al., 2015; Smith et al., 2015; King et al., 2016) making time-varying evolution of the supraglacial drainage patterns difficult to capture. Due to this limitation, current routing models commonly assume supraglacial drainage pattern and efficiency are temporally static, although some simple parameterizations of routing distance or velocity may be used to mimic the temporal evolution of meltwater routing (Yang et al., 2020; Gleason et al., 2021). Our finding of a direct, correlative $R-D_{d}$ relationship suggests that a simpler, alternative approach may be to parameterize this evolution directly from climate model output (Figure 3). By correlating intermittently available VHR images with modeled runoff, it appears possible to approximate the time-varying evolution of supraglacial drainage patterns in a

This article is protected by copyright. All rights reserved. 
seamless and continuous way.

\subsection{Supraglacial drainage efficiency follows an elevational gradient}

The temporal and elevational variations in $D_{d}$ presented here (Figures $\mathbf{2}, \mathbf{3}$, and S3-S5) introduce large differences in the timing and diurnal range of surface runoff delivered to supraglacial catchment outlets, which causes an order-of-magnitude reduction in the diurnal variability of surface runoff as compared to standard climate model output alone (Figures 7 and 8). This is mainly attributed to a combination of smaller $D_{d}$ (inducing smaller channel networks and larger interfluves), higher $A_{c}$, and larger, flatter catchments at high elevation (Yang and Smith, 2016), which delay and attenuate the lateral transport of runoff across the ice surface (Table 1).

Notably, since we extrapolate meltwater routing velocities calibrated at mid-elevation ( 1300 m) Catchment 2 (characterized by low density weathering crust, Cooper et al. (2018)) to estimate routing velocities at high-elevation ( $1500-1700 \mathrm{~m})$ Catchment 4 commonly covered in snow and firn (i.e. above the end-of-summer $1549 \pm 144 \mathrm{~m}$ snowline, Ryan et al. (2019)), the high-elevation meltwater routing velocities presented here are likely too high. This renders our conclusion of suppressed diurnal runoff variability at high elevations conservative, and providing only an upper bound for this variability (Figures $\mathbf{7 d}$ and $\mathbf{8 d}$ ).

\subsection{Potential importance of the elevational $D_{d}$ gradient to ice flow dynamics}

Because surface meltwater runoff entering moulins modifies subglacial effective pressure and ice flow velocity (Andrews et al., 2014; Banwell et al., 2016; Flowers, 2018;

This article is protected by copyright. All rights reserved. 
Koziol and Arnold, 2018), we speculate that the up-elevation decline in diurnal runoff variability - which correspondingly reduces diurnal variability of moulin input - might potentially contribute to previous observations of reduced short-term variability in ice velocity at higher elevations previously linked to diurnal cycles in surface melting (Shepherd et al., 2009; Bartholomew et al., 2011).

Diurnal fluctuations in meltwater-supply variability drive short-term ice motion even more than absolute subglacial water storage (Iken et al., 1983; Bartholomaus et al., 2008; Schoof, 2010; Hoffman et al., 2011; Cowton et al., 2016; Andrews et al., 2018; Armstrong and Anderson, 2020), which was recently confirmed using in situ discharge and GPS ice motion measurements at Catchment 2 (Smith et al., 2021). Our findings suggest that in a warming climate, increasing runoff production at high elevations will lead to higher $D_{d}$ (Figure $\mathbf{3}$ ), thus routing runoff to moulins faster and with greater diurnal variability than today. As per Smith et al. (2021), this, in turn, may enhance short-term accelerations in ice motion due solely to increased diurnal variability of moulin inputs.

Because ice thickness, basal and surface slopes, strain rates, and other factors also influence ice velocity, a direct linkage between $D_{d}$, diurnal variability of moulin input, and ice motion remains untested. Due to thicker ice (which promotes conduit closure), the dynamical effect of this likely differs at higher elevations. Doyle et al. (2014), for example, found that high-elevation $(>1700 \mathrm{~m}$ ) ice experiences persistent ice flow acceleration and attributed it to seasonal melt and supraglacial lake drainage. Our findings imply that increasing diurnal surface runoff variability (Figures $\mathbf{7}$ and $\mathbf{8}$ ) due to increased supraglacial drainage efficiency (i.e. high $D_{d}$ ) might also contribute to subglacial water pressure and ice

This article is protected by copyright. All rights reserved. 
dynamics, in addition to overall surface runoff and moulin input (Covington et al., 2020; Andrews et al., 2021).

\subsection{Advantages of $A_{c}$ for simulating continuous, temporally evolving drainage networks}

VHR satellite-mapped supraglacial streams reflect a combination of surface melt, topographic, and ice/firn/snow processes, whereas ArcticDEM modeled drainage networks reflect only the effect of topography. Therefore, it is unsurprising that these two types of networks exhibit differences in stream distribution (Figures 2 and S3-S5). However, these differences have marginal impacts on streamflow simulated by spatially-lumped routing models if the DEM resolution is sufficient (Zhang and Montgomery, 1994; McMaster, 2002; Yang et al., 2014). The $5 \mathrm{~m}$ resolution ArcticDEM analyzed here appears sufficient for capturing the overall pattern of satellite-mapped supraglacial stream networks and reproducing supraglacial stream abundance over a catchment.

Although $A_{c}$ may not capture the precise real-world location of all supraglacial streams, it remains a promising parameter to simulate continuous, temporally evolving DEM-modeled drainage networks for the purpose of driving lumped surface routing models for several reasons: first, these simulated networks expand or contract naturally in response to runoff variations (i.e., networks expand outward from river-mainstems when runoff generation increases, and contract inward toward mainstems when runoff decreases (Godsey and Kirchner, 2014; Schneider et al., 2017; van Meerveld et al., 2019); second, unlike mapped stream networks which commonly have discontinuities, ArcticDEM modeled drainage networks are continuous, a prerequisite for routing models (Yang et al., 2018; Gleason et al.,

This article is protected by copyright. All rights reserved. 
2021); and third, based on the quantitative $D_{d}-A_{c}$ relationship, ArcticDEM modeled drainage networks appear to reasonably reflect stream abundance, which is crucial for interfluve vs. open channel partitioning. With future progress in multi-temporal satellite stream mapping, better understanding of ice surface properties and higher resolution modeled runoff, spatially varying $D_{d}-A_{c}$ relationships are feasible.

\subsection{Prospects for a more universal $R$ - $D_{d}$ relationship}

The empirical $R-D_{d}$ relationship presented here (Figure $\mathbf{3}$ ) is a first demonstration of an empirical technique to estimate temporal and spatial variations in ice surface runoff transport efficiency, but has several limitations. Temporally, diurnal expansions and contractions of supraglacial streams are substantial but we cannot assess $D_{d}$ diurnal variability due to similar time-of-day satellite image sampling (Table S1 and Text S1). In the future, VHR images acquired at different times of day will enable investigation of diurnal $D_{d}$ variations. Furthermore, the lumped UH may not be sufficient to handle these rapid variations so a spatially distributed routing model is required to estimate the impacts of diurnal $D_{d}$ variations on runoff transport. Spatially, large scale implementation of our approach requires further testing and validation in other areas of the ice sheet. While obtained using different elevations, catchments, and times (Figures 2, and S3-S5, Table 1), the southwestern GrIS is the most melt-intensive area of Greenland (Fettweis et al., 2020), characterized by bare glacial ice (Ryan et al., 2019), high supraglacial drainage efficiency (Smith et al., 2015), and porous, low density, water-saturated bare ice (Cooper et al., 2018; Irvine-Fynn et al., 2021). For areas where surface melting is less intense (e.g. northern and

This article is protected by copyright. All rights reserved. 
eastern Greenland), both the empirical $R-D_{d}$ relationship and the optimal way to estimate it may differ. For example, the runoff smoothing (i.e. moving average) parameter is likely to be longer than five days because longer time is required to route meltwater. Importantly, more $D_{d}$ observations are required for snow- and firn-covered areas. Above the seasonal snowline ( $\sim 1500 \mathrm{~m}$ in this area, Ryan et al. (2019)), the slope of the $R-D_{d}$ linear relationship is likely smaller due to meltwater retention in snow and firn (Harper et al., 2012; Mikkelsen et al., 2016; Steger et al., 2017), reduced open-channel development, and channel infilling with slush (Mikkelsen et al., 2016). The underlying calibration required to compute $v_{h}$ and $v_{c}$ is likely non-transferable because the physical mechanism for meltwater flowing through snow/firn and bare ice differs (Banwell et al., 2012; Leeson et al., 2012; Yang et al., 2018).

Acquisition of new supraglacial discharge datasets from other, snowier parts of the ice sheet would thus broaden the applicability of the approach presented here. A more universal $R-D_{d}$ relationship will require consideration of other ice surface conditions besides bare ice. Acquisition of field-measured or remotely sensed ice surface physical properties (e.g. density, permeability, and porosity (Zuo and Oerlemans, 1996; Harper et al., 2012; Mikkelsen et al., 2016; Steger et al., 2017; Cooper et al., 2018; Ryan et al., 2019)) sampled concurrently with measurements of runoff/discharge would provide exceedingly valuable calibration data for this purpose.

\section{Conclusions}

Climate models offer continuous simulations of GrIS surface runoff at hourly or daily time steps, and high-resolution satellite mapping affords occasional glimpses of supraglacial

This article is protected by copyright. All rights reserved. 
drainage density $\left(D_{d}\right)$. By correlating climate model outputs of runoff with intermittent VHR satellite maps of $D_{d}$, we find an empirical correlation between runoff and $D_{d}$ along an elevational gradient on the southwestern GrIS. By combining this $R-D_{d}$ relationship with a simple surface routing model, we effectively characterize temporal variations in supraglacial drainage efficiency. Incorporation of spatial and temporal variations in $D_{d}$ into the routing model reveals a strong elevational gradient in the diurnal timing and magnitude of runoff transport to catchment outlets - in particular decreasing diurnal variability at higher elevations - that is not reflected in standard climate model output. This supraglacial modification likely creates elevational gradients in moulin input timing and associated subglacial water pressures due solely to surface drainage patterns. A broader implication of this finding is the potential for parameterizing surface runoff routing efficiency directly from climate model output. This research thus advances the link between climate/SMB models, surface routing models, and ice dynamics; and improves current knowledge of GrIS supraglacial drainage efficiency in areas of differing melt intensity and supraglacial stream/river development.

\section{Acknowledgements}

K. Yang acknowledges support from the National Natural Science Foundation of China (41871327), the Strategic Priority Research Program of the Chinese Academy of Sciences (XDA19070201), the Frontiers Science Center for Critical Earth Material Cycling Fund (JBGS2102), and the Fundamental Research Funds for the Central Universities (14380097). L.C. Smith and L.C. Andrews acknowledge support from the NASA Cryospheric Science

This article is protected by copyright. All rights reserved. 
Program (grant 80NSSC19K0942) managed by Dr. Thorsten Markus. High-resolution WorldView and Quickbird satellite images and ArcticDEMs were provided by the Polar Geospatial Center at the University of Minnesota under NSF-OPP awards 1043681, 1559691, and 1542736 and processed at the University of California, Los Angeles under NASA Cryospheric Sciences (grant NNX14AH93G). The supraglacial stream detection codes are freely available at https://github.com/njuRS/River_detection. Data used to generate results reported in this study are available through Figshare (https://doi.org/10.6084/m9.figshare.14615940.v1). We thank the Associate Editor, Caroline Clason, Stephen Livingstone, and an anonymous reviewer for their thoughtful, constructive comments.

This article is protected by copyright. All rights reserved. 


\section{References:}

Abrahams, A.D. (1984) Channel Networks: A Geomorphological Perspective, Water Resour. Res. 20(2), 161-188.

Allen, G.H., Pavelsky, T.M., Barefoot, E.A., Lamb, M.P., Butman, D., Tashie, A., \& Gleason, C.J. (2018) Similarity of stream width distributions across headwater systems, Nat. Commun. 9(1), 610.

Andrews, L.C., Catania, G.A., Hoffman, M.J., Gulley, J.D., Luthi, M.P., Ryser, C., Hawley, R.L., \& Neumann, T.A. (2014) Direct observations of evolving subglacial drainage beneath the Greenland Ice Sheet, Nature 514(7520), 80-83.

Andrews, L.C., Hoffman, M.J., Neumann, T.A., Catania, G.A., Lüthi, M.P., Hawley, R.L., Schild, K.M., Ryser, C., \& Morriss, B.F. (2018) Seasonal evolution of the subglacial hydrologic system modified by supraglacial lake drainage in western Greenland, J. Geophys. Res. Earth Surf. O(ja).

Andrews, L.C., Poinar, K., \& Trunz, C. (2021) Controls on Greenland moulin geometry and evolution from the Moulin Shape model, The Cryosphere Discuss. 2021, 1-47.

Armstrong, W.H., \& Anderson, R.S. (2020) Ice-marginal lake hydrology and the seasonal dynamical evolution of Kennicott Glacier, Alaska, J. Glaciol. 66(259), 699-713.

Banwell, A.F., Arnold, N.S., Willis, I.C., Tedesco, M., \& Ahlstrøm, A.P. (2012) Modeling supraglacial water routing and lake filling on the Greenland Ice Sheet, J. Geophys. Res. 117(F4), F04012.

Banwell, A.F., Hewitt, I., Willis, I., \& Arnold, N. (2016) Moulin density controls drainage development beneath the Greenland Ice Sheet, J. Geophys. Res. Earth Surf. 121(12), 2248-2269.

Banwell, A.F., Willis, I.C., \& Arnold, N.S. (2013) Modeling subglacial water routing at Paakitsoq, W Greenland, J. Geophys. Res. Earth Surf. 118(3), 1282-1295.

Bartholomaus, T.C., Anderson, R.S., \& Anderson, S.P. (2008) Response of glacier basal motion to transient water storage, Nat. Geosci. 1(1), 33-37.

Bartholomew, I.D., Nienow, P., Sole, A., Mair, D., Cowton, T., King, M.A., \& Palmer, S. (2011) Seasonal variations in Greenland Ice Sheet motion: Inland extent and behaviour at higher elevations, Earth Planet. Sci. Lett. 307(3-4), 271-278.

Bosilovich, M.G., Akella, S., Coy, L., Cullather, R., Draper, C., \& Gelaro, R. (2016). MERRA-2. Initial evaluation of the climate. In R.D. Koster (Ed.), Technical Report Series on Global Modeling and Data Assimilation. Greenbelt, Maryland: National Aeronautics and Space Administration

Chow, G.C. (1960) Tests of Equality Between Sets of Coefficients in Two Linear Regressions, Econometrica 28(3), 591-605.

Clason, C.C., Mair, D.W.F., Nienow, P.W., Bartholomew, I.D., Sole, A., Palmer, S., \& Schwanghart, W. (2015) Modelling the transfer of supraglacial meltwater to the bed of Leverett Glacier, Southwest Greenland, Cryosph. 9(1), 123-138.

Colgan, W., Steffen, K., McLamb, W.S., Abdalati, W., Rajaram, H., Motyka, R., Phillips, T., \& Anderson, R. (2011) An increase in crevasse extent, West Greenland: Hydrologic implications, Geophys. Res. Lett. 38(18), L18502.

Cooper, M.G., Smith, L.C., Rennermalm, A.K., Miège, C., Pitcher, L.H., Ryan, J.C., Yang, K., \& Cooley, S. (2018) Meltwater storage in low-density near-surface bare ice in the Greenland ice sheet ablation zone, Cryosph. 12, 955-970.

Covington, M.D., Gulley, J.D., Trunz, C., Mejia, J., \& Gadd, W. (2020) Moulin Volumes Regulate Subglacial Water Pressure on the Greenland Ice Sheet, Geophys. Res. Lett. 47(20), e2020GL088901.

This article is protected by copyright. All rights reserved. 
Cowton, T.O.M., Nienow, P., Sole, A., Bartholomew, I.A.N., \& Mair, D. (2016) Variability in ice motion at a land-terminating Greenlandic outlet glacier: the role of channelized and distributed drainage systems, J. Glaciol. 62(233), 451-466.

Crozier, J., Karlstrom, L., \& Yang, K. (2018) Basal control of supraglacial meltwater catchments on the Greenland Ice Sheet, Cryosph. 12, 3383-3407.

Davison, B.J., Sole, A.J., Livingstone, S.J., Cowton, T.R., \& Nienow, P.W. (2019) The influence of hydrology on the dynamics of land-terminating sectors of the Greenland Ice Sheet, Front. Earth Sci. 7(10).

de Fleurian, B., Morlighem, M., Seroussi, H., Rignot, E., van den Broeke, M.R., Kuipers Munneke, P., Mouginot, J., Smeets, P.C.J.P., \& Tedstone, A.J. (2016) A modeling study of the effect of runoff variability on the effective pressure beneath Russell Glacier, West Greenland, J. Geophys. Res. Earth Surf. 121(10), 1834-1848.

Decaux, L., Grabiec, M., Ignatiuk, D., \& Jania, J. (2018) Role of discrete water recharge from supraglacial drainage systems in modeling patterns of subglacial conduits in Svalbard glaciers, Cryosph. 2019(13), 735-752.

Dingman, S.L. (2015). Physical hydrology (3rd edition). Waveland press

Doyle, S.H., Hubbard, A., Fitzpatrick, A.A.W., van As, D., Mikkelsen, A.B., Pettersson, R., \& Hubbard, B. (2014) Persistent flow acceleration within the interior of the Greenland ice sheet, Geophys. Res. Lett. 41(3), 899-905.

Fettweis, X., Hofer, S., Krebs-Kanzow, U., Amory, C., Aoki, T., Berends, C.J., Born, A., Box, J.E., Delhasse, A., Fujita, K., Gierz, P., Goelzer, H., Hanna, E., Hashimoto, A., Huybrechts, P., Kapsch, M.L., King, M.D., Kittel, C., Lang, C., Langen, P.L., Lenaerts, J.T.M., Liston, G.E., Lohmann, G., Mernild, S.H., Mikolajewicz, U., Modali, K., Mottram, R.H., Niwano, M., Noël, B., Ryan, J.C., Smith, A., Streffing, J., Tedesco, M., van de Berg, W.J., van den Broeke, M., van de Wal, R.S.W., van Kampenhout, L., Wilton, D., Wouters, B., Ziemen, F., \& Zolles, T. (2020) GrSMBMIP: Intercomparison of the modelled 1980-2012 surface mass balance over the Greenland Ice sheet, Cryosph. 14(11), 39353958.

Fitzpatrick, A.A.W., Hubbard, A.L., Box, J.E., Quincey, D.J., van As, D., Mikkelsen, A.P.B., Doyle, S.H., Dow, C.F., Hasholt, B., \& Jones, G.A. (2014) A decade of supraglacial lake volume estimates across a land-terminating margin of the Greenland Ice Sheet, Cryosph. 8(1), 107-121.

Flowers, G.E. (2018) Hydrology and the future of the Greenland Ice Sheet, Nat. Commun. 9(1), 2729. Gleason, C.J., Yang, K., Feng, D., Smith, L.C., Liu, K., Pitcher, L.H., Chu, V.W., Cooper, M.G., Overstreet, B.T., Rennermalm, A.K., \& Ryan, J.C. (2021) Hourly surface meltwater routing for a Greenlandic supraglacial catchment across hillslopes and through a dense topological channel network, Cryosph. 15(5), 2315-2331.

Godsey, S.E., \& Kirchner, J.W. (2014) Dynamic, discontinuous stream networks: hydrologically driven variations in active drainage density, flowing channels and stream order, Hydrological Processes 28(23), 5791-5803.

Goulden, T., Hopkinson, C., Jamieson, R., \& Sterling, S. (2014) Sensitivity of watershed attributes to spatial resolution and interpolation method of LiDAR DEMs in three distinct landscapes, Water Resour. Res. 50(3), 1908-1927.

Hall, D.K., Cullather, R.I., DiGirolamo, N.E., Comiso, J.C., Medley, B.C., \& Nowicki, S.M. (2018) A Multilayer Surface Temperature, Surface Albedo, and Water Vapor Product of Greenland from MODIS, Remote Sensing 10(4), 555.

This article is protected by copyright. All rights reserved. 
Harper, J., Humphrey, N., Pfeffer, W.T., Brown, J., \& Fettweis, X. (2012) Greenland ice-sheet

contribution to sea-level rise buffered by meltwater storage in firn, Nature 491(7423), 240-243.

Hoffman, M.J., Catania, G.A., Neumann, T.A., Andrews, L.C., \& Rumrill, J.A. (2011) Links between acceleration, melting, and supraglacial lake drainage of the western Greenland Ice Sheet, J. Geophys. Res. Earth Surf. 116(F4).

Holmes, G. (1955). Morphology and hydrology of the Mint Julep area, southwest Greenland. In, Project Mint Julep Part II (pp. 1-50): Maxwell Air Force Base, AL, Air University

Ignéczi, Á., Sole, A.J., Livingstone, S.J., Ng, F.S.L., \& Yang, K. (2018) Greenland Ice Sheet surface topography and drainage structure controlled by the transfer of basal variability, Front. Earth Sci. 6, 101.

Iken, A., Röthlisberger, H., Flotron, A., \& Haeberli, W. (1983) The Uplift of Unteraargletscher at the Beginning of the Melt Season-A Consequence of Water Storage at the Bed?, J. Glaciol. 29(101), 28-47.

Irvine-Fynn, T.D.L., Edwards, A., Stevens, I.T., Mitchell, A.C., Bunting, P., Box, J.E., Cameron, K.A., Cook, J.M., Naegeli, K., Rassner, S.M.E., Ryan, J.C., Stibal, M., Williamson, C.J., \& Hubbard, A. (2021) Storage and export of microbial biomass across the western Greenland Ice Sheet, Nat. Commun. 12(1), 3960.

Karlstrom, L., \& Yang, K. (2016) Fluvial supraglacial landscape evolution on the Greenland Ice Sheet, Geophys. Res. Lett. 43, 2683-2692.

King, L., Hassan, M., Yang, K., \& Flowers, G. (2016) Flow routing for delineating supraglacial meltwater channel networks, Remote Sens. 8(12), 988.

Knighton, A.D. (1985) Channel form Adjustment in Supraglacial Streams, Austre Okstindbreen, Norway, Arc. Antarct. Res. 17(4), 451-466.

Koziol, C.P., \& Arnold, N. (2018) Modelling seasonal meltwater forcing of the velocity of landterminating margins of the Greenland Ice Sheet, Cryosph. 12(3), 971-991.

Lampkin, D.J., \& VanderBerg, J. (2014) Supraglacial melt channel networks in the Jakobshavn Isbræ region during the 2007 melt season, Hydrolo. Process. 28(25), 6038-6053.

Leeson, A.A., Shepherd, A., Palmer, S., Sundal, A., \& Fettweis, X. (2012) Simulating the growth of supraglacial lakes at the western margin of the Greenland ice sheet, Cryosph. 6(5), 1077-1086.

Lefebre, F., Gallée, H., van Ypersele, J.-P., \& Greuell, W. (2003) Modeling of snow and ice melt at ETH Camp (West Greenland): A study of surface albedo, J. Geophys. Res. Atmospheres 108(D8), 16.

Lindsay, J.B. (2016) Efficient hybrid breaching-filling sink removal methods for flow path enforcement in digital elevation models, Hydrolo. Process. 30(6), 846-857.

Lu, Y., Yang, K., Lu, X., Smith, L.C., Sole, A.J., Livingstone, S.J., Fettweis, X., \& Li, M. (2020) Diverse supraglacial drainage patterns on the Devon ice Cap, Arctic Canada, J. Maps 16(2), 834-846.

Marston, R.A. (1983) Supraglacial stream dynamics on the Juneau icefield, Ann. Assoc. Am. Geogr. 73(4), 597-608.

McGrath, D., Colgan, W., Steffen, K., Lauffenburger, P., \& Balog, J. (2011) Assessing the summer water budget of a moulin basin in the Sermeq Avannarleq ablation region, Greenland ice sheet, $J$. Glaciol. 57(205), 954-964.

McMaster, K.J. (2002) Effects of digital elevation model resolution on derived stream network positions, Water Resour. Res. 38(4), 13-11-13-18.

Mikkelsen, A.B., Hubbard, A., MacFerrin, M., Box, J.E., Doyle, S.H., Fitzpatrick, A., Hasholt, B., Bailey, H.L., Lindbäck, K., \& Pettersson, R. (2016) Extraordinary runoff from the Greenland ice sheet in

This article is protected by copyright. All rights reserved. 
2012 amplified by hypsometry and depleted firn retention, Cryosph. 10(3), 1147-1159.

Miller, J.R., Russell, G.L., \& Caliri, G. (1994) Continental-Scale River Flow in Climate Models, J. Clim 7(6), 914-928.

Montgomery, D.R., \& Dietrich, W.E. (1989) Source areas, drainage density, and channel initiation, Water Resour. Res. 25(8), 1907-1918.

Muthyala, R., Rennermalm, A.K., Leidman, S.Z., Cooper, M.G., Cooley, S.W., Smith, L.C., \& van As, D. (2020) Seasonal Variability in In-situ Supraglacial Streamflow and Drivers in Southwest Greenland in 2016, The Cryosphere Discuss. 2020, 1-28.

Nghiem, S.V., Hall, D.K., Mote, T.L., Tedesco, M., Albert, M.R., Keegan, K., Shuman, C.A., DiGirolamo, N.E., \& Neumann, G. (2012) The extreme melt across the Greenland ice sheet in 2012, Geophys. Res. Lett. 39(20).

Pitcher, L.H., \& Smith, L.C. (2019) Supraglacial Streams and Rivers, Annu. Rev. Earth Planet. Sci. 47(1), null.

Pitcher, L.H., Smith, L.C., \& Gleason, C.J. (2016) CryoSheds: a GIS modeling framework for delineating land-ice watersheds for the Greenland Ice Sheet, GIsci. Remote Sens. 53(6), 707-722.

Poinar, K., \& Andrews, L.C. (2020) Challenges in predicting Greenland supraglacial lake drainages at the regional scale, Cryosph. 15(3), 1455-1483.

Poinar, K., Joughin, I., Das, S.B., Behn, M.D., Lenaerts, J.T.M., \& van den Broeke, M.R. (2015) Limits to future expansion of surface-melt-enhanced ice flow into the interior of western Greenland, Geophys. Res. Lett. 42, 1800-1807.

Prancevic, J.P., \& Kirchner, J.W. (2019) Topographic Controls on the Extension and Retraction of Flowing Streams, Geophys. Res. Lett. 46(4), 2084-2092.

Reichle, R.H., Draper, C.S., Liu, Q., Girotto, M., Mahanama, S.P.P., Koster, R.D., \& Lannoy, G.J.M.D. (2017) Assessment of MERRA-2 Land Surface Hydrology Estimates, J. Clim. 30(8), 2937-2960.

Rippin, D.M., Pomfret, A., \& King, N. (2015) High resolution mapping of supra-glacial drainage pathways reveals link between micro-channel drainage density, surface roughness and surface reflectance, Earth Surf. Process. Landf. 40(10), 1279-1290.

Ryan, J.C., Smith, L.C., van As, D., Cooley, S.W., Cooper, M.G., Pitcher, L.H., \& Hubbard, A. (2019) Greenland Ice Sheet surface melt amplified by snowline migration and bare ice exposure, Sci. Adv. 5(3), eaav3738.

Schneider, A., Jost, A., Coulon, C., Silvestre, M., Théry, S., \& Ducharne, A. (2017) Global-scale river network extraction based on high-resolution topography and constrained by lithology, climate, slope, and observed drainage density, Geophys. Res. Lett. 44(6), 2773-2781.

Schoof, C. (2010) Ice-sheet acceleration driven by melt supply variability, Nature 468, 803. Shepherd, A., Hubbard, A., Nienow, P., King, M., McMillan, M., \& Joughin, I. (2009) Greenland ice sheet motion coupled with daily melting in late summer, Geophys. Res. Lett. 36(1).

Smith, L.C., Andrews, L.C., Pitcher, L.H., Overstreet, B.T., Rennermalm, Å.K., Cooper, M.G., Cooley, S.W., Ryan, J.C., Miège, C., Kershner, C., \& Simpson, C.E. (2021) Supraglacial River Forcing of Subglacial Water Storage and Diurnal Ice Sheet Motion, Geophys. Res. Lett. 48(7), e2020GL091418.

Smith, L.C., Chu, V.W., Yang, K., Gleason, C.J., Pitcher, L.H., Rennermalm, A.K., Legleiter, C.J., Behar, A.E., Overstreet, B.T., Moustafa, S.E., Tedesco, M., Forster, R.R., LeWinter, A.L., Finnegan, D.C., Sheng, Y., \& Balog, J. (2015) Efficient meltwater drainage through supraglacial streams and rivers on the southwest Greenland ice sheet, Proc. Natl. Acad. Sci. 112(4), 1001-1006.

Smith, L.C., Yang, K., Pitcher, L.H., B.T., O., Chu, V.W., Rennermalm, A.K., Ryan, J., Cooper, M.G.,

This article is protected by copyright. All rights reserved. 
Gleason, C.J., \& Tedesco, M. (2017) Direct measurements of meltwater runoff on the Greenland ice sheet surface, Proc. Natl. Acad. Sci. 114(50), E10622-E10631.

Sneed, W.A., \& Hamilton, G.S. (2007) Evolution of melt pond volume on the surface of the Greenland Ice Sheet, Geophys. Res. Lett. 34(3), L03501.

Steger, C.R., Reijmer, C.H., van den Broeke, M.R., Wever, N., Forster, R.R., Koenig, L.S., Kuipers Munneke, P., Lehning, M., Lhermitte, S., Ligtenberg, S.R.M., Miège, C., \& Noël, B.P.Y. (2017) Firn Meltwater Retention on the Greenland Ice Sheet: A Model Comparison, Front. Earth Sci. 5(3).

Sundal, A.V., Shepherd, A., Nienow, P., Hanna, E., Palmer, S., \& Huybrechts, P. (2009) Evolution of supra-glacial lakes across the Greenland Ice Sheet, Remote Sens. Environ. 113(10), 2164-2171.

Tarboton, D.G., Bras, R.L., \& Rodrigueziturbe, I. (1991) On the extraction of channel networks from digital elevation data, Hydrolo. Process. 5(1), 81-100.

Tedesco, M., Fettweis, X., Mote, T., Wahr, J., Alexander, P., Box, J.E., \& Wouters, B. (2013) Evidence and analysis of 2012 Greenland records from spaceborne observations, a regional climate model and reanalysis data, Cryosph. 7(2), 615-630.

Tucker, G.E., \& Bras, R.L. (1998) Hillslope processes, drainage density, and landscape morphology, Water Resour. Res. 34(10), 2751-2764.

van Meerveld, H.J.I., Kirchner, J.W., Vis, M.J.P., Assendelft, R.S., \& Seibert, J. (2019) Expansion and contraction of the flowing stream network alter hillslope flowpath lengths and the shape of the travel time distribution, Hydrol. Earth Syst. Sci. 23(11), 4825-4834.

Vernon, C.L., Bamber, J.L., Box, J.E., van den Broeke, M.R., Fettweis, X., Hanna, E., \& Huybrechts, P. (2013) Surface mass balance model intercomparison for the Greenland ice sheet, Cryosph. 7(2), 599-614.

Yang, K., Karlstrom, L., Smith, L.C., \& Li, M. (2017) Automated high resolution satellite image registration using supraglacial rivers on the Greenland Ice Sheet, IEEE J. Sel. Topics Appl. Earth Observ. Remote Sens. 10(3), 845-856.

Yang, K., \& Smith, L.C. (2013) Supraglacial streams on the Greenland ice sheet delineated from combined spectral-shape information in high-resolution satellite imagery, IEEE Geosci. Remote Sens. Lett. 10(4), 801-805.

Yang, K., \& Smith, L.C. (2016) Internally drained catchments dominate supraglacial hydrology of the southwest Greenland Ice Sheet, J. Geophys. Res. Earth Surf. 121, 1891-1910.

Yang, K., Smith, L.C., Cooper, M.G., Pitcher, L.H., van As, D., Lu, Y., Lu, X., \& Li, M. (2021) Seasonal evolution of supraglacial lakes and rivers on the southwest Greenland Ice Sheet, J. Glaciol., 1-11.

Yang, K., Smith, L.C., Fettweis, X., Gleason, C.J., Lu, Y., \& Li, M.C. (2019a) Surface meltwater runoff on the Greenland ice sheet estimated from remotely sensed supraglacial lake infilling rate, Remote Sens. Environ. 234, 12.

Yang, K., Smith, L.C., Karlstrom, L., Cooper, M.G., Tedesco, M., As, D.v., Cheng, X., Chen, Z., \& Li, M. (2018) A new surface meltwater routing model for use on the Greenland Ice Sheet surface, Cryosph. 12(12), 3791-3811.

Yang, K., Smith, L.C., Sole, A., Livingstone, S.J., Cheng, X., Chen, Z., \& Li, M. (2019b) Supraglacial rivers on the northwest Greenland Ice Sheet, Devon Ice Cap, and Barnes Ice Cap mapped using Sentinel-2 imagery, Int. J. Appl. Earth Obs. 78, 1-13.

Yang, K., Sommers, A., Andrews, L.C., Smith, L.C., Lu, X., Fettweis, X., \& Li, M. (2020) Intercomparison of surface meltwater routing models for the Greenland ice sheet and influence on subglacial effective pressures, Cryosph. 14(10), 3349-3365.

This article is protected by copyright. All rights reserved. 
Yang, P., Ames, D.P., Fonseca, A., Anderson, D., Shrestha, R., Glenn, N.F., \& Cao, Y. (2014) What is the effect of LiDAR-derived DEM resolution on large-scale watershed model results?, Environ. Model. Softw. 58, 48-57.

Zhang, W., \& Montgomery, D.R. (1994) Digital elevation model grid size, landscape representation, and hydrologic simulations, Water Resour. Res. 30(4), 1019-1028.

Zuo, Z., \& Oerlemans, J. (1996) Modelling albedo and specific balance of the Greenland ice sheet: calculations for the Søndre Strømfjord transect, J. Glaciol. 42(141), 305-317.

This article is protected by copyright. All rights reserved. 
Figure 1. Four supraglacial study catchments (black polygons) on the southwestern Greenland Ice Sheet (GrIS) are used to investigate the correlation of climate model runoff and supraglacial stream drainage density $\left(D_{d}\right)$ mapped from very high-resolution (VHR, 0.5 m) satellite images. Catchment 4-1 is inside Catchment 4 and used for sensitivity analysis (green polygon). Previously published high-resolution stream maps (not shown) are available for Catchments m1-m4 from Smith et al. (2015) (red polygons) and King et al. (2016) (purple polygons). These previously published maps, all manually delineated from 2012 WorldView-1 images, are used to independently validate the empirical $R-D_{d}$ relationship derived from Catchments 1-4. Catchment topographic boundaries are extracted from $5 \mathrm{~m}$ ArcticDEM data; coarser-resolution supraglacial river networks and lakes (blue lines) are derived from an August 2013 Landsat-8 panchromatic image (Yang and Smith, 2016). Superimposed grids show the cells of MAR $(7.5 \times 7.5 \mathrm{~km})$ and MERRA-2 $(56 \times 28 \mathrm{~km})$ climate models in gray and green lines respectively. Background is a Sentinel-2 image acquired on 30 July 2018.

Figure 2. Catchment 3 supraglacial drainage pattern as estimated from ArcticDEM (upper left panel), and from multi-temporal very high-resolution (VHR, $0.5 \mathrm{~m}$ ) panchromatic satellite images (dates shown). The green dot shows the catchment outlet. A close-up view of the extremely well-developed supraglacial stream/river network observed on 2012.07 .31 is presented in Figure S2.

Figure 3. Relationship between supraglacial stream drainage density $\left(D_{d}\right)$ mapped from very high-resolution (VHR, $0.5 \mathrm{~m}$ ) satellite images and surface runoff $(R)$ simulated by (a) MAR and (b) MERRA-2 climate models. The corresponding linear regression functions are then used to estimate $D_{d}$ evolution using solely climate model outputs of runoff. (c) and (d) are

This article is protected by copyright. All rights reserved. 
similar to (a) and (b) but with the four different catchments color coded.

Figure 4. (a) Relationship between supraglacial stream drainage density $\left(D_{d}\right)$ and cumulative upstream contributing area $\left(A_{c}\right)$ necessary to initiate supraglacial channels on $5 \mathrm{~m}$ resolution ArcticDEM for Catchments 1-4, where (b) shows the corresponding surface runoff that controls $D_{d}$ variations . For $D_{d}<60 \mathrm{~km}^{-1}$ the empirical $D_{d}-A_{c}$ curves for the four catchments are similar. A generalized fitting curve can be obtained over this range, enabling calculation of $A_{c}$ from $D_{d}$, to partition bulk interfluve and open-channel areas for the catchment. (c) and (d) are similar to (a) and (b) but show the $D_{d}-A_{c}$ relationship obtained for the $10 \mathrm{~m}$ resolution ArcticDEM. The $D_{d}-A_{c}$ relationship is scale-dependent so the $D_{d}-A_{c}$ curves show large variations approaching the limit of the resolution of the ArcticDEM.

Figure 5. A simple empirical relationship relating modeled runoff from the MAR and MERRA2 climate models, together with associated supraglacial stream drainage density $\left(D_{d}\right)$, and estimated mean interfluve routing time $\left(t_{h}\right)$ necessary for runoff to reach the channelized stream/river network.

Figure 6. (a) Hourly and (b) daily unit hydrographs (UHs) derived from variable partitions of interfluve and open-channel zones for Catchment 3, which is determined by open-channel initiation thresholds $\left(A_{c}\right)$, stream drainage density $\left(D_{d}\right)$, and climate model runoff simulations. Figure 7. Instantaneous hourly MAR surface runoff and routed hourly runoff derived from hourly UHs for catchments 1-4 during summer 2015. At higher elevations, diurnal variability in the surface-routed runoff hydrograph is dampened and delayed, owing to decreased stream drainage density $\left(D_{d}\right)$ associated with lower runoff production.

Figure 8. Average daily cycles of instantaneous vs. surface-routed runoff for Catchments 1-4

This article is protected by copyright. All rights reserved. 
during summer 2015.

Table 1. Summary of study supraglacial catchments. Field-calibrated open channel velocity $\left(v_{c}\right)$ and interfluve velocity $\left(v_{h}\right)$ are $0.4 \mathrm{~m} / \mathrm{s}$ and $0.0006 \mathrm{~m} / \mathrm{s}$ respectively. The mean topographic slope of each catchment is used to adjust these field-calibrated velocities.

This article is protected by copyright. All rights reserved. 


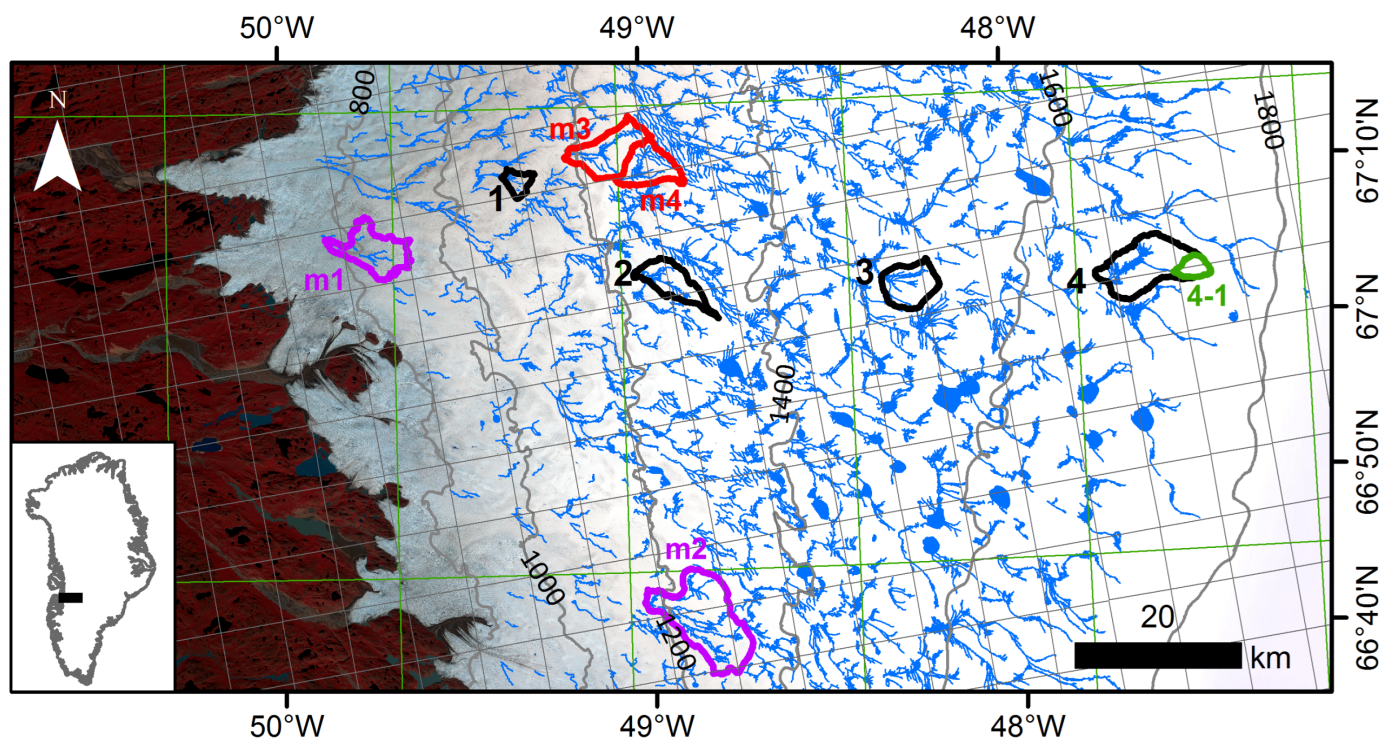

This article has been accepted for publication and undergone full peer review but has not been through the copyediting, typesetting, pagination and proofreading process, which may lead to differences between this version and the Version of Record. Please cite this article as doi: 10.1029/2021JF006269.

This article is protected by copyright. All rights reserved. 


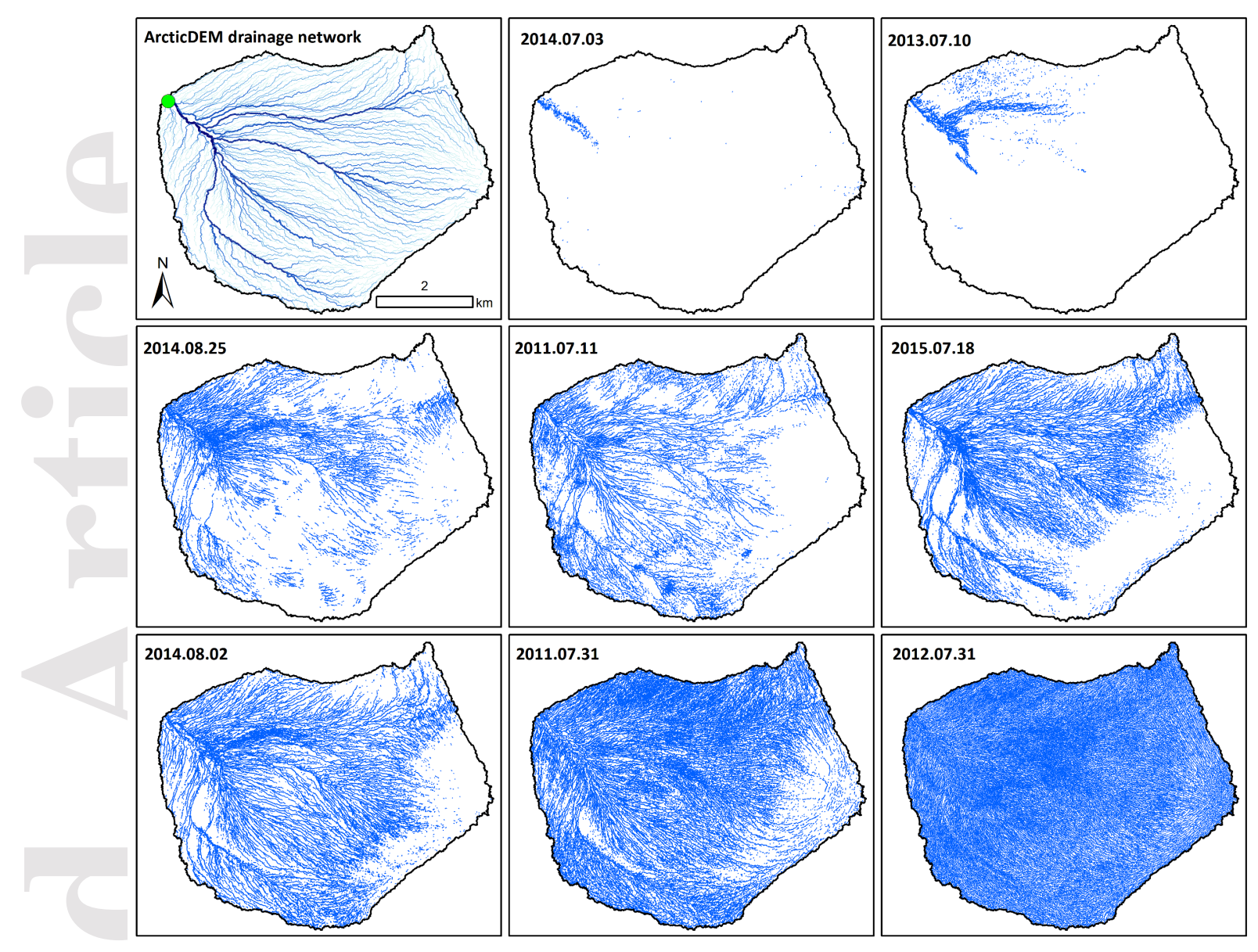

This article is protected by copyright. All rights reserved. 

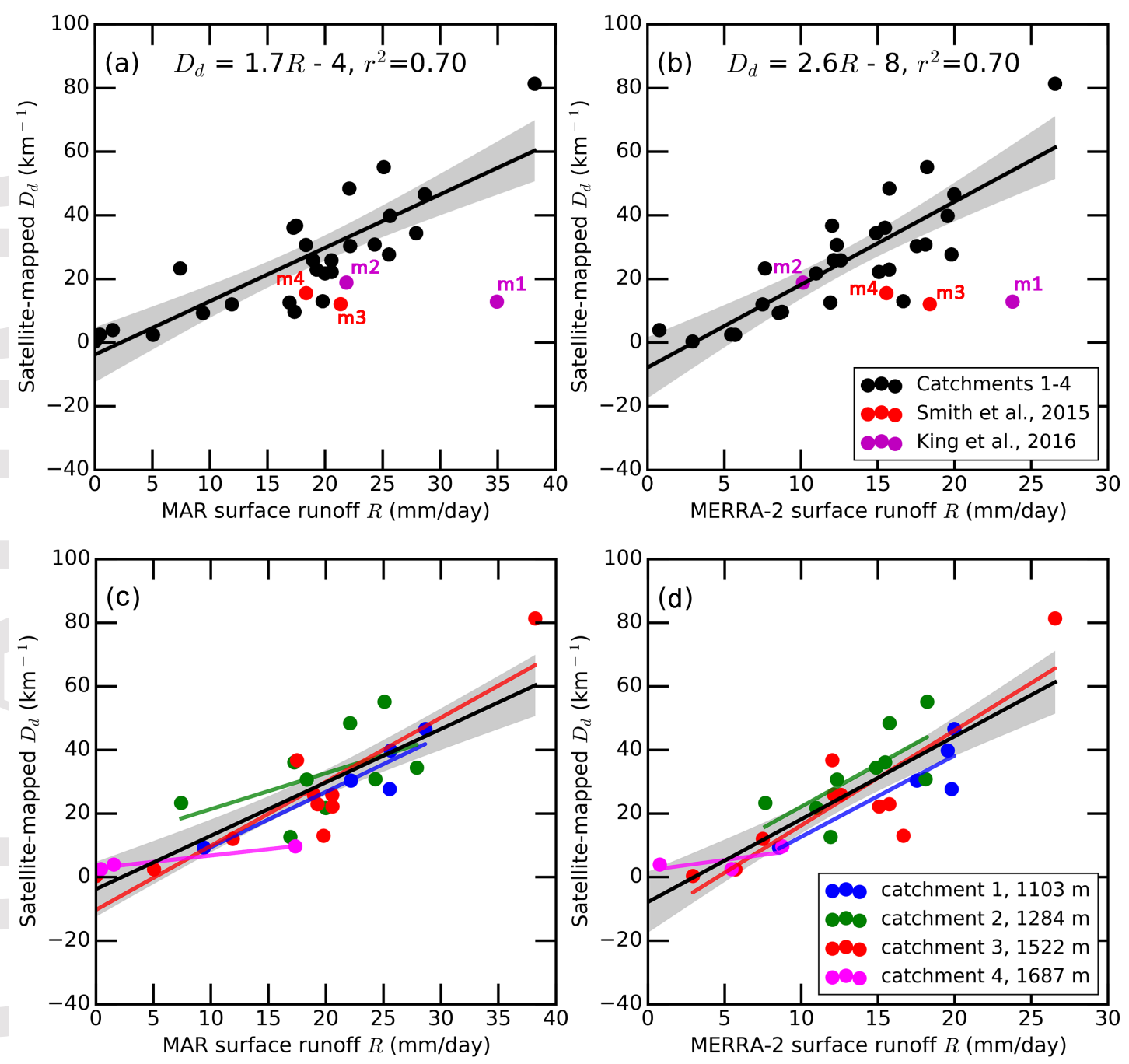

This article is protected by copyright. All rights reserved. 

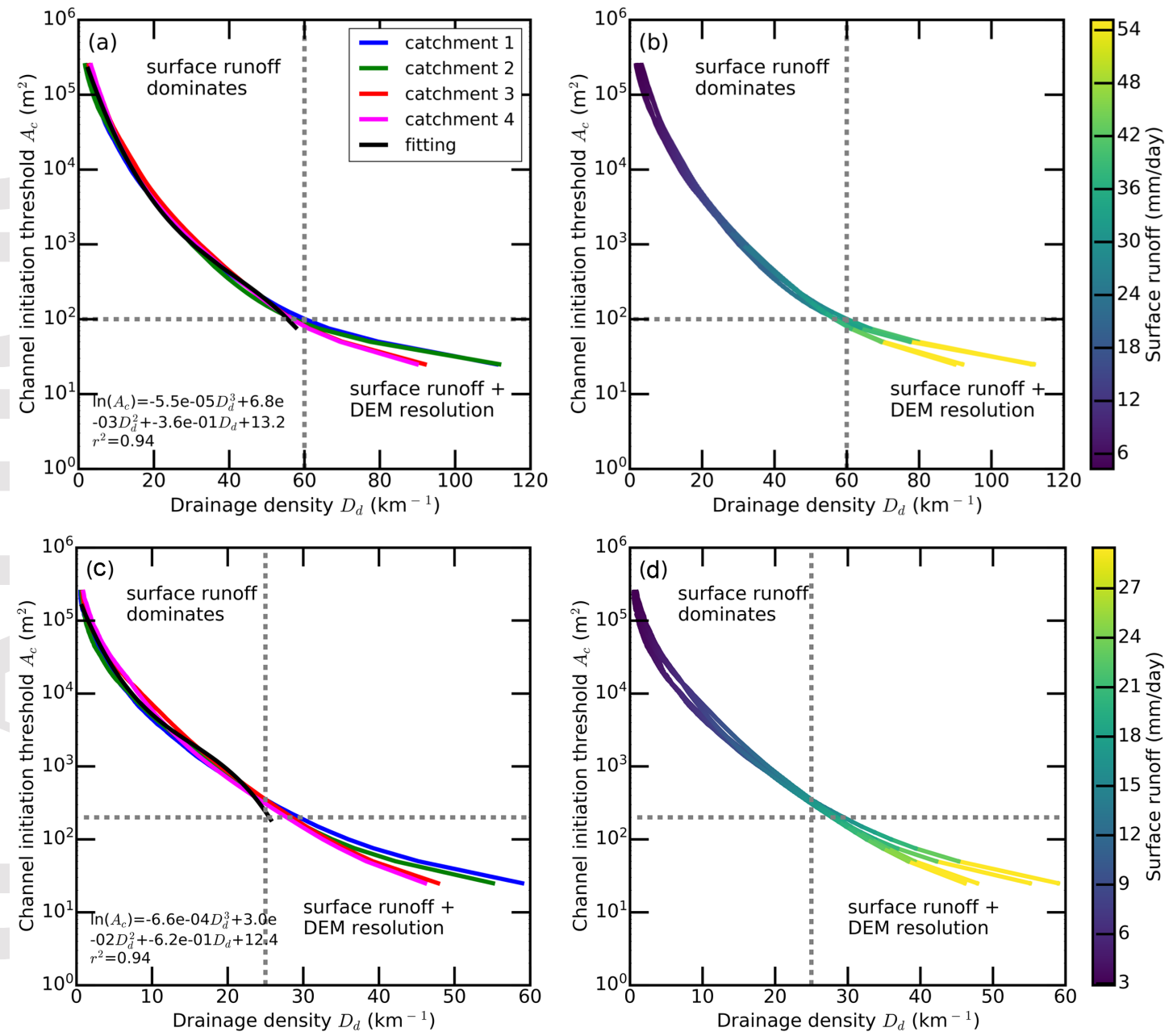

This article is protected by copyright. All rights reserved. 


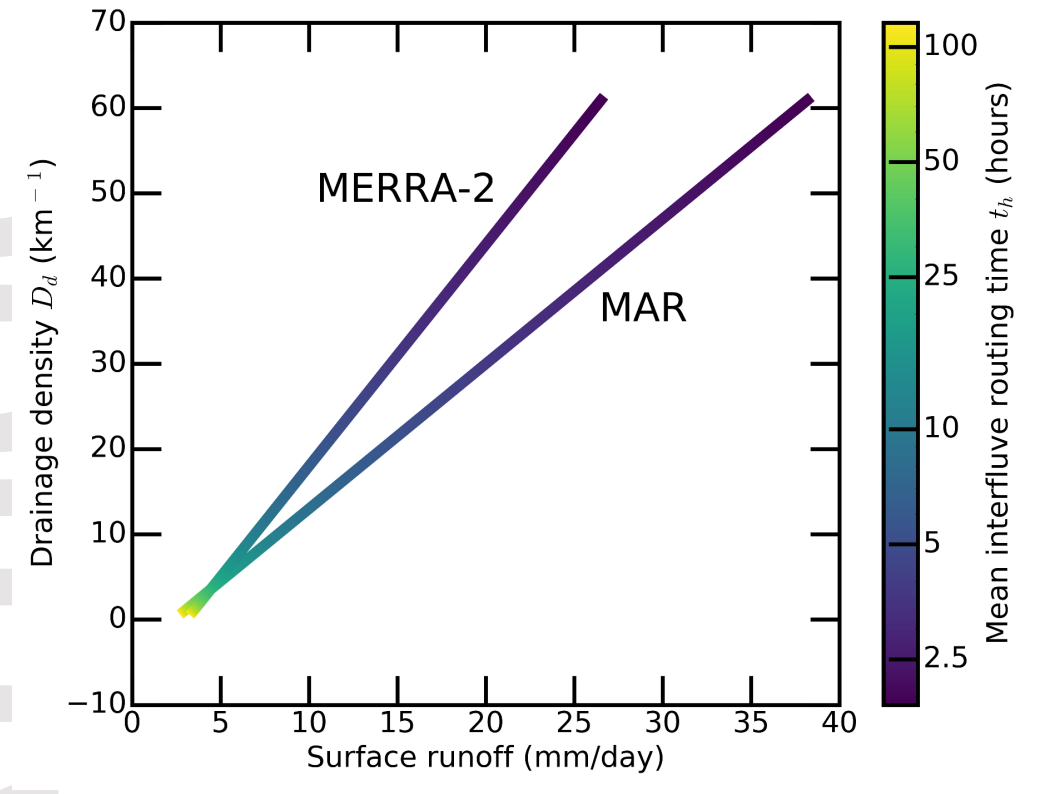

This article is protected by copyright. All rights reserved. 

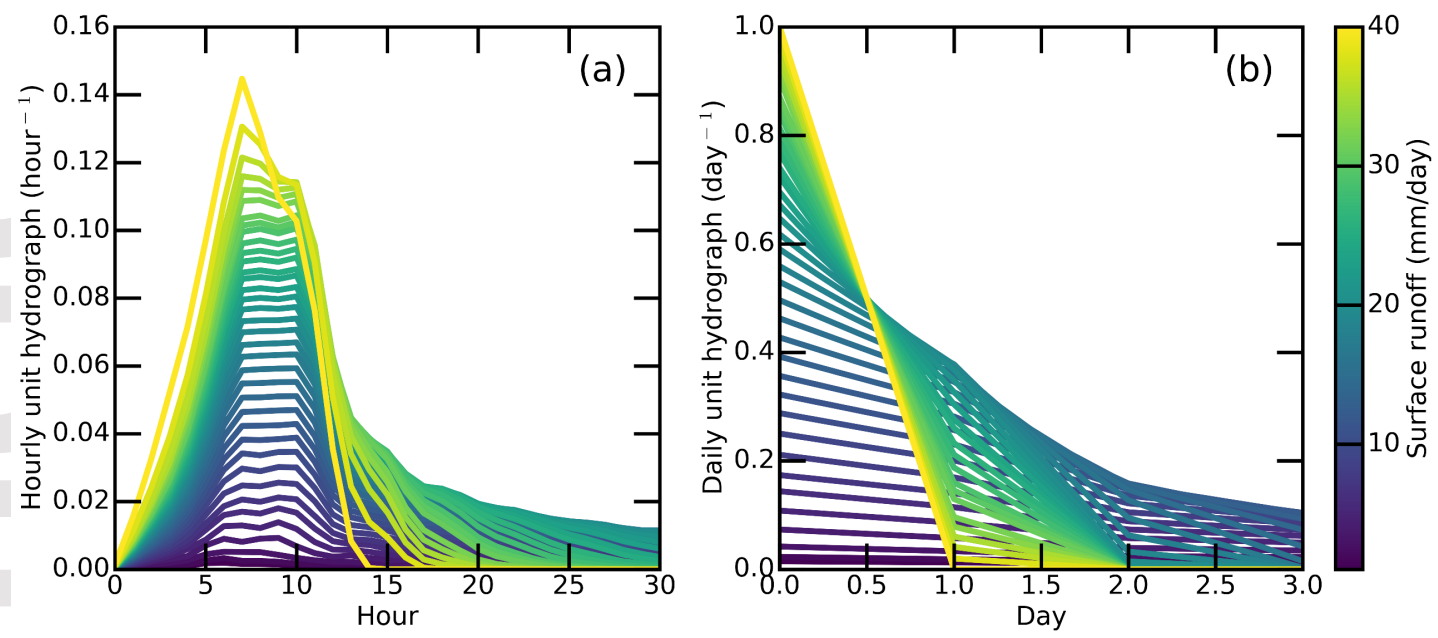

This article is protected by copyright. All rights reserved. 


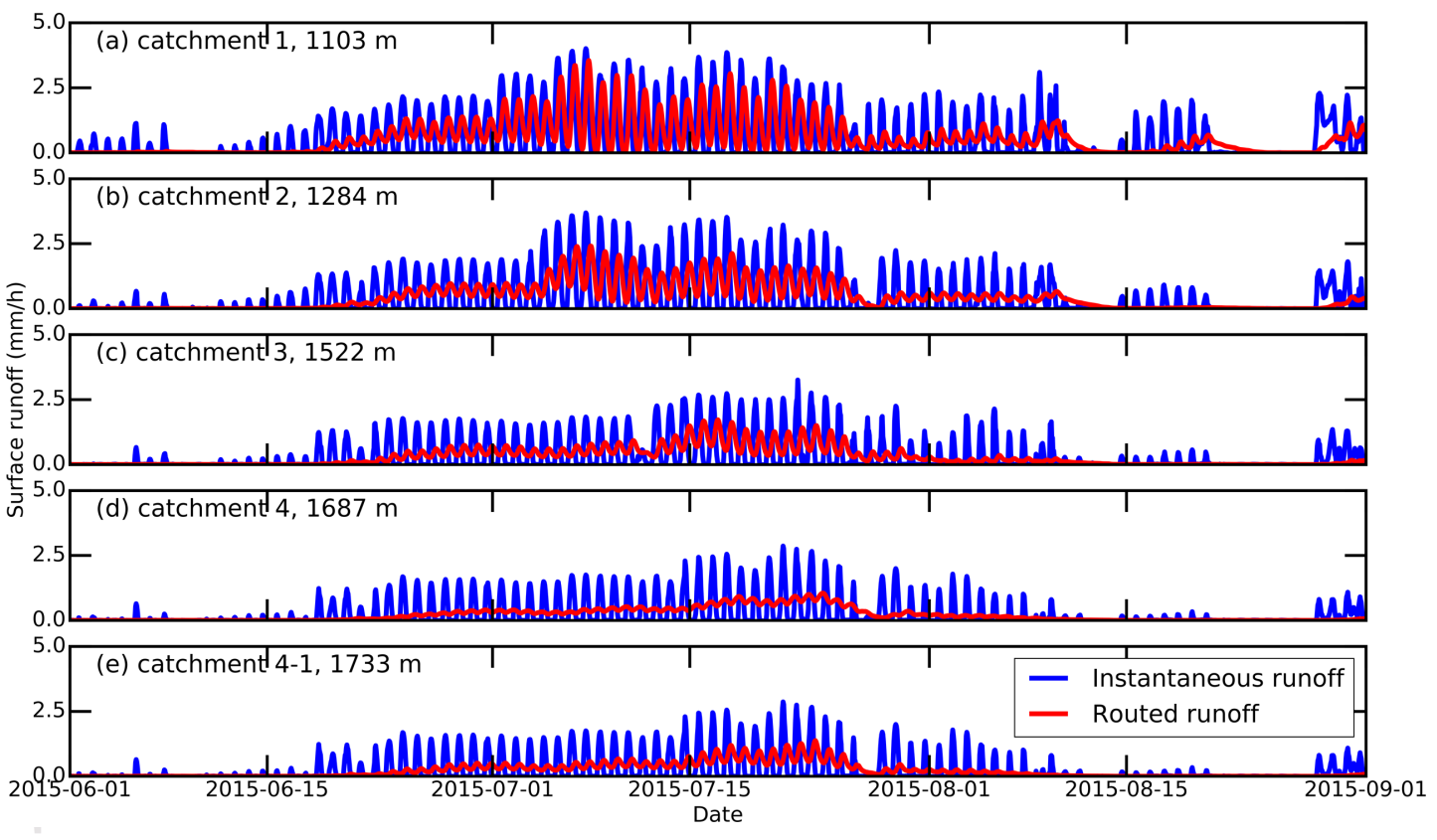

This article is protected by copyright. All rights reserved. 

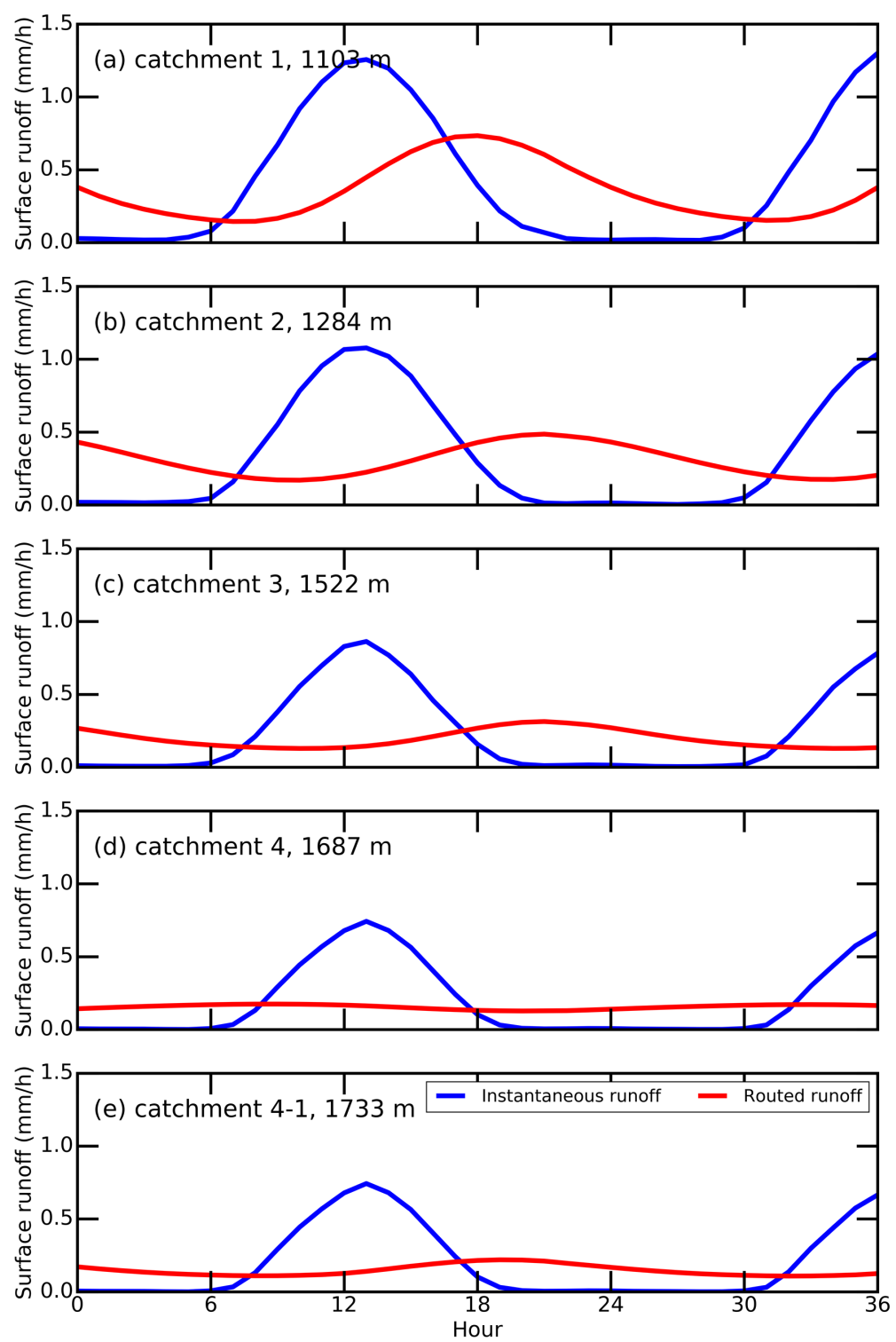

This article is protected by copyright. All rights reserved. 


\begin{tabular}{|c|c|c|c|c|c|c|}
\hline \multicolumn{2}{|c|}{ Catchment ID } & $\begin{array}{l}\text { Catchment } \\
1\end{array}$ & $\begin{array}{l}\text { Catchment } \\
2\end{array}$ & $\begin{array}{c}\text { Catchment } \\
3\end{array}$ & $\begin{array}{c}\text { Catchment } \\
4\end{array}$ & $\begin{array}{c}\text { Catchment } \\
\text { 4-1 }\end{array}$ \\
\hline \multicolumn{2}{|c|}{ Area $\left(\mathrm{km}^{2}\right)$} & 7.2 & 24.3 & 28.5 & 59.2 & 7.8 \\
\hline \multicolumn{2}{|c|}{ Mean Elevation (m) } & 1103 & 1284 & 1522 & 1687 & 1733 \\
\hline \multicolumn{2}{|c|}{ Mean topographic slope $(\mathrm{m} / \mathrm{m})$} & 0.035 & 0.034 & 0.025 & 0.021 & 0.015 \\
\hline \multicolumn{2}{|c|}{$\begin{array}{c}\text { Mean ice flow velocity (m/a) } \\
(2015-2016)\end{array}$} & 118 & 109 & 99 & 73 & 69 \\
\hline \multicolumn{2}{|c|}{ Distance to ice edge (km) } & 28 & 44 & 73 & 99 & 103 \\
\hline \multicolumn{2}{|c|}{ Satellite river mapping times } & 5 & 9 & 10 & 3 & 3 \\
\hline \multirow{2}{*}{$\begin{array}{c}\text { Slope-adjusted } \\
\text { water velocity } \\
\text { (m/s) }\end{array}$} & open-channel $v_{c}$ & 0.41 & 0.40 & 0.34 & 0.31 & 0.27 \\
\hline & Interfluve $v_{h}$ & 0.00061 & 0.00060 & 0.00051 & 0.00047 & 0.00040 \\
\hline \multirow{3}{*}{$\begin{array}{l}\text { Peak timing of } \\
\text { diurnal MAR } \\
\text { runoff }\end{array}$} & instantaneous & 13 & 13 & 13 & 13 & 13 \\
\hline & $\begin{array}{c}\text { routed with } \\
\text { slope-adjusted } v\end{array}$ & 18 & 21 & 21 & 9 (+ one day) & 19 \\
\hline & $\begin{array}{l}\text { routed with field- } \\
\text { calibrated } v\end{array}$ & 18 & 21 & 19 & 1 (+ one day) & 17 \\
\hline \multirow{3}{*}{$\begin{array}{c}\text { Range of } \\
\text { diurnal MAR } \\
\text { runoff }(\mathrm{mm} / \mathrm{h})\end{array}$} & instantaneous & 1.30 & 1.07 & 0.86 & 0.74 & 0.74 \\
\hline & $\begin{array}{c}\text { routed with } \\
\text { slope-adjusted } v\end{array}$ & 0.62 & 0.32 & 0.18 & 0.05 & 0.11 \\
\hline & $\begin{array}{l}\text { routed with field- } \\
\text { calibrated } v\end{array}$ & 0.61 & 0.32 & 0.23 & 0.11 & 0.15 \\
\hline
\end{tabular}

This article is protected by copyright. All rights reserved. 